\title{
Current status of the effectiveness of essential oils for controlling phytopathogenic fungi, a review
}

\author{
Estado actual de la efectividad de aceites esenciales para el control \\ de hongos fitopatógenos, una revisión
}

Silvia Bautista-Baños ${ }^{1}$, Zormy Nacary Correa-Pacheco ${ }^{2}$, Jaime Black-Solis ${ }^{1,3^{*}}$

\author{
${ }^{1}$ Centro de Desarrollo de Productos Bióticos (CEPROBI), Instituto Politécnico Nacional, Carretera Yautepec-Jojutla, Km. 6, \\ Calle Ceprobi No. 8, 62731, Yautepec, Morelos, México. \\ ${ }^{2}$ CONACYT-CEPROBI. \\ 3Programa REM Ecuador, Calle Andalucía y Luis Cordero, c.p. 170525, Quito, Pichincha, Ecuador. \\ ${ }^{*}$ Corresponding author: jblacks1500@alumno.ipn.mx
}

Received:

August 29, 2019

Accepted:

April 8, 2020

Published:

July 15, 2020

This is an open access article distributed according the Creative Commons license terms.

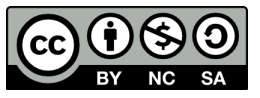

Attribution-NonCommercialShareAlike 4.0 International

\section{ABStract}

Essential oils (EOs) are volatile plant derivatives that have been evaluated in the control of phytopathogenic fungi, and whose effectiveness has been associated with the part of the plant and concentration used. Hereby we provide an overview of the role of EOs on phytopathogenic fungi agents, presenting an overview of its diversity, constituents, tests under in vivo and in vitro conditions, their mechanisms of action, and the techniques to assess its effectiveness. The antimicrobial action of EOs is attributed to their ability to penetrate through cell membranes and inhibit the functional properties of fungal cells.

\section{KEYWORDS}

Hydrodistillation, secondary metabolites, in vitro and in vivo studies, direct contact and vapor phase techniques, coatings and bioactive films.

\section{RESUMEN}

Los aceites esenciales (AEs) son derivados volátiles de plantas que han sido evaluados en el control de hongos fitopatógenos y su efectividad se ha asociado con la parte de la planta y la concentración utilizada. Aquí presentamos una revisión del papel de los AEs en el control de hongos fitopatógenos, con una panorámica de su diversidad, constituyentes, pruebas bajo condiciones in vivo e in vitro, sus mecanismos de acción y las técnicas para evaluar su efectividad. La acción antimicrobiana de los AEs se atribuye a su capacidad para penetrar las membranas celulares e inhibir las propiedades funcionales de las células fúngicas.

PALABRAS CLAVE

Hidrodestilación, metabolitos secundarios, estudios in vitro e in vivo, técnicas de contacto directo y fase de vapor, recubrimientos y películas bioactivas 


\section{INTRODUCTION}

Phytopathogenic fungi are responsible for diseases in a large number of vegetable and fruit products, which may appear during crop development or postharvest (Mamgain et al. 2013). There are several methods considered to minimize losses and maintain the quality and safety of the horticultural product, being the application of chemical treatments one of the most widely used (Ruiz et al. 2012). Still, mismanagement and the presence of residues cause human health to be affected as well as resistant strains to be generated (McCarroll et al. 2002).

The purpose of the present review is to present an in-depth analysis of the information that is available on the aforementioned subject, to position the use and effectiveness of Essential oils (EOs) as a state-ofthe-art alternative to control phytopathogenic fungi. In this study, EOs from 54 plant species were found to exhibit a potential role as a fungicide on 60 different fungal species. Also, this information will serve as the basis for selecting the most effective EOs for future applications into biodegradable systems in various horticultural commodities.

EOs are volatile plant derivatives (Franz and Novak 2009; Krisch et al. 2011), which are responsible for their aroma. In the plant, they serve several purposes: as messengers, attractors of pollinators, and as a defense against herbivores and microorganisms that cause diseases. This last characteristic is what confers its properties as an agent for the control of phytopathogenic fungi (Baser and Buchbauer 2009; Kubeczka 2009).

Since the Middle Ages, EOs have been used by man, not only as flavor and food preservatives, but also as cosmetics, aphrodisiacs, and medicine (Dima and Dima 2015; Mandal and Mandal 2015), as well as for the protection and control of pests and diseases in stored grains (Isman 2000). For example, a study published in 1880 describes the activity of cinnamon essential oil for the control of anthrax bacilli (Kocić-Tanackov and Dimić 2013).

Currently, there are about 2,000 species of plants from which EOs have been obtained, and around 300 of them are commercially available (Raut and Karuppayil 2014). The EOs can be obtained from various parts of the plant (Krisch et al. 2011). For example, from the aerial part, chia (Salvia hispanica L.) (Elshafie et al. 2018), mint (Mentha spicata L.) (Kedia et al. 2015), and rue (Ruta graveolens L.) (Haddouchi et al. 2013); from leaves, basil (Ocimum selloi Benth.) (Costa et al. 2015), and orange (Citrus sinensis (L.) Osbeck.) (Hamdani and Allem 2015); from flowers, chamomile (Matricaria chamomilla L.) (Lu et al. 2013), and gypsy grass (Bupleurum falcatum L.) (Mohammadi et al. 2014); from bark, cinnamon (Cinnamomum zeylanicum Blume.) (Black-Solis et al. 2017); from the root, santolina (Santolina chamaecyparissus L.) (Salah-Fatnassi et al. 2017); from the rhizome, white ginger (Hedychium coronarium J. Koenig.) (Ray et al. 2018); from fruits, hemlock (Cicuta virosa var. latisecta Čelak.) (Tian et al. 2011a), and from seeds, dill (Anethum graveolens L.) (Ma et al. 2015a) and cumin (Cuminum cyminum L.) (Kedia et al. 2014b).

Conventionally, EOs can be obtained by two processes: cold pressure and distillation. There are several methods in connection to the latter, like hydrodistillation, and steam distillation (which can be used with high pressure) (Kubeczka 2009). EOs can also be obtained through other methods, like extraction with organic solvents, with liquid carbon dioxide, with supercritical fluids, and with microwaves (Ma et al. 2015b; Mansoreh et al. 2015; Pavlić et al. 2015; Torrenegra et al. 2015).

The content of components and the effectiveness of EOs in the control of phytopathogenic fungi depend on several factors, including the part of the plant used to obtain the EO, its concentration, as well as the environmental conditions and stress to which the botanical species was subjected during their development (Schmidt 2009), among other factors.

\section{CONSTITUENT COMPONENTS OF EOs}

Plants produce a series of secondary metabolites (more than 100,000 identified) classified into nitrogen-free compounds (terpenes, polyketides, phenolics, saponins, and polyacetylenes), and nitrogen-containing compounds (alkaloids, amines, cyanogenic glycosides, non-protein amino acids, glucosinolates, alkamides, and peptides) (Wink 2010).

Many components that constitute EOs and which are mixtures of low molecular weight compounds (between 85 and 99\%) are volatile. 
The main constituents are derived from three routes of biosynthesis: the mono and diterpenes from the methyl-erythritol pathway, the sesquiterpenes from the mevalonate pathway, and the phenylpropenes from the shikimic acid pathway (Franz and Novak 2009).

Terpenes are the combinations of isoprene molecules (5 carbon unit -C5), monoterpenes (C10), diterpenes (C20), and sesquiterpenes (C15). Terpenoids are terpenes that contain oxygen in their structure. Phenylpropane derivatives are aromatic compounds, such as aldehydes (citral), alcohols (geraniol), and phenols (thymol) (Sánchez-González et al. 2011).

In almost all the studies carried out, the identification and quantification of the constitutive components of EOs were made utilizing the gas chromatography technique coupled to mass spectrometry (GC-MS). Another method which is used with a lower frequency is the thin layer chromatography (Gemeda et al. 2015).
An EO can be constituted by more than 100 different components and in differing proportions, which can vary depending on the effect of the species (Dima and Dima 2015). There are plant species in which the main component amounted to more than $80 \%$ of the EO (Table 1). For example, in spice cloves (Eugenia caryophyllus, Spreng) (Bullock \& S.G.Harrison), eugenol represents $90.5 \%$ (Castro et al. 2017); for basil (O. selloi), methyl chavicol constitutes $93.2 \%$ of the total (Costa et al. 2015); in orange (C. sinensis), DL-limonene, $90.6 \%$ (Singh et al. 2010); in pulicaria (Pulicaria mauritanica Batt.), carvotanacetone, 87.3\% (Znini et al. 2013); in oregano (Origanum vulgare L.), carvacrol, $86.9 \%$ (Zabka et al. 2014); in mountain rue (Ruta angustifolia Pers.), 2-undecanone, $82.4 \%$ (Haddouchi et al. 2013); in clove (Syzygium aromaticum (L.) Merr. \& L.M.Perry.), eugenol, $82.3 \%$ (Manganyi et al. 2015), and in cinnamon (C. zeylanicum) trans-cinnamaldehyde represented $80.4 \%$ (Lu et al. 2013).

Table 1. Plant species, main compounds identified and relative percentage, of EOs used for in vitro and in vivo evaluations against phytopathogenic fungi.

\begin{tabular}{|c|c|c|c|}
\hline Plant species & EO main compounds & Relative percentage & Reference \\
\hline Solidago canadensis L. & Germacrene D, limonene & $34.9,12.5$ & Elshafie et al. 2019 \\
\hline $\begin{array}{l}\text { Helichrysum microphyllum } \\
\text { subsp. tyrrhenicum Bacch. \& al. }\end{array}$ & $\begin{array}{l}\text { Neryl acetate, c-curcumene, } \\
\text { farnesene, 5-eudesmen-11-ol }\end{array}$ & $33.6,11.5,7.3,4.3$ & Juliano et al. 2019 \\
\hline Salvia officinalis L. & $\begin{array}{l}\text { 1.8-Cineole, } \alpha \text {-thujone, } \\
\text { camphor }\end{array}$ & $14.6,20.6,19.3$ & Rguez et al. 2019 \\
\hline $\begin{array}{l}\text { Rabdosia rugosus Wall. (Syn. } \\
\text { Plectranthus rugosus Wall.) }\end{array}$ & $\alpha$-bisabolol & 41.9 & Singh et al. 2019 \\
\hline Salvia hispanica L. & $\begin{array}{l}\text { (Z)-caryophyllene, (E)- } \\
\text { caryophyllene }\end{array}$ & $11.5,10.6$ & Elshafie et al. 2018 \\
\hline $\begin{array}{l}\text { Hedychium coronarium } \mathrm{J} . \\
\text { Koenig. }\end{array}$ & $\begin{array}{l}\beta \text {-pinene, eucalyptol, linalool, } \\
\text { coronarin-E, } \alpha \text {-pinene, } \\
\text { Q-cymene }\end{array}$ & $\begin{array}{l}12.7-42.7,7.3-42.2,1.9- \\
45.1,1.0-39.5,3.8-16.6 \\
1.2-13.3\end{array}$ & Ray et al. 2018 \\
\hline $\begin{array}{l}\text { Melaleuca alternifolia (Maiden \& } \\
\text { Betche) Cheel. }\end{array}$ & $\begin{array}{l}\text { Terpinene- } 4 \text {-ol, } \gamma \text {-terpinene, } \\
\alpha \text {-terpinene }\end{array}$ & $31.1,25.3,12.7$ & Zhang et al. 2018 \\
\hline $\begin{array}{l}\text { Cinnamomum zeylanicum } \\
\text { Blume. } \\
\text { Cymbopogon flexuosus (Nees ex } \\
\text { Steud.) W.Watson. } \\
\text { Eucalyptus globulus Labill. } \\
\text { Eugenia caryophyllus (Spreng.) } \\
\text { Bullock \& S.G.Harrison. } \\
\text { Rosmarinus officinalis L. }\end{array}$ & $\begin{array}{l}\text { Eugenol } \\
\text { E-Caryophyllene, geranial, } \\
\text { geraniol, neral } \\
\text { 1,8-cineole } \\
\text { Eugenol } \\
\alpha \text {-pinene, 1,8-cineole, camphor }\end{array}$ & $\begin{array}{l}80.0 \\
21.4,15.3,14.5 \\
14.1 \\
78.9 \\
90.5 \\
24.5,19.4,22.0\end{array}$ & Castro et al. 2017 \\
\hline $\begin{array}{l}\text { Helichrysum italicum (Roth) } \\
\text { G.Don. }\end{array}$ & $\begin{array}{l}\alpha \text {-cedrene, } \alpha \text {-curcumene, } \\
\text { geranyl acetate }\end{array}$ & $13.6,11.4,10.0$ & Djihane et al. 2017 \\
\hline
\end{tabular}




\begin{tabular}{|c|c|c|c|}
\hline Plant species & EO main compounds & Relative percentage & Reference \\
\hline Ocimum selloi Benth. & Methyl chavicol & 93.2 & Costa et al. 2015 \\
\hline $\begin{array}{l}\text { Trachyspermum copticum (L.) } \\
\text { Link. (Syn. Trachyspermum } \\
\text { ammi (L.) Sprague.) }\end{array}$ & Thymol, Q-cimene, $\gamma$-terpinene & $29.6,16.0,17.8$ & $\begin{array}{l}\text { Khosravi et al. } \\
2015\end{array}$ \\
\hline Anethum graveolens L. & Limonene, carvone, apiol & $32.6,41.5,16.7$ & Ma et al. 2015a \\
\hline $\begin{array}{l}\text { Thymus vulgaris L. } \\
\text { Lippia rehmannii H.Pearson. } \\
\text { Syzygium aromaticum (L.) Merr. } \\
\text { \& L.M.Perry. } \\
\text { Cinnamomum zeylanicum }\end{array}$ & $\begin{array}{l}\text { Thymol, terpinen-4-ol } \\
\text { Geranial, neral } \\
\text { Eugenol, } \beta \text {-Caryophyllene } \\
\text { Eugenol }\end{array}$ & $\begin{array}{l}45.2,12.3 \\
34.5,20.2 \\
82.3,11.0 \\
12.8\end{array}$ & $\begin{array}{l}\text { Manganyi et al. } \\
2015\end{array}$ \\
\hline $\begin{array}{l}\text { Thymus vulgaris } \\
\text { Pelargonium odoratissimum (L.) } \\
\text { L'Hér. }\end{array}$ & $\begin{array}{l}\text { Q-cimene, thymol } \\
\beta \text {-citronellol, geraniol }\end{array}$ & $\begin{array}{l}21.9,44.6 \\
24.8,12.5\end{array}$ & $\begin{array}{l}\text { Matusinsky et al. } \\
2015\end{array}$ \\
\hline $\begin{array}{l}\text { Thymus vulgaris } \\
\text { Cinnamomum cassia L. }\end{array}$ & $\begin{array}{l}\text { Thymol, } \mathrm{Q} \text {-cimene, } \gamma \text {-terpinene } \\
\text { Cinnamaldehyde, cinnamyl } \\
\text { acetate }\end{array}$ & $\begin{array}{l}35.6,19.5,10.5 \\
73.6,3-15\end{array}$ & $\begin{array}{l}\text { Pekmezovic et al. } \\
2015\end{array}$ \\
\hline $\begin{array}{l}\text { Anthemis odontostephana Boiss. } \\
\text { Var. odontostephana }\end{array}$ & $\begin{array}{l}\text { Flower: borneol, (-)-bornyl } \\
\text { acetate } \\
\text { Leaf: borneol, myristicin } \\
\text { Stem: borneol, myristicin }\end{array}$ & $\begin{array}{l}\text { Flor: } 31.3,13.9 \\
\text { Hoja: } 19.2,13.3 \\
\text { Tallo: } 27.0,11.2\end{array}$ & $\begin{array}{l}\text { Zebarjad and } \\
\text { Farjam } 2015\end{array}$ \\
\hline Artemisia monosperma Delile. & Capylene, capilin, $\gamma$-terpinene & $36.8,14.6,12.4$ & $\begin{array}{l}\text { Badawy and } \\
\text { Abdelgaleil } 2014\end{array}$ \\
\hline Cymbopogon nardus (L.) Rendle. & $\begin{array}{l}\text { Citronellal, citronellol, } \\
\text { geraniol }\end{array}$ & $26.2,12.9,19.7$ & Chen et al. 2014 \\
\hline Mentha spicata L. & DL-Limonene, dextro-carvone & $25.5,59.6$ & Kedia et al. 2014a \\
\hline Cuminum cyminum L. & $\begin{array}{l}\text { Laevo } \beta \text {-pinene, cimeno, } \\
\gamma \text {-terpinene, cuminaldehyde }\end{array}$ & $11.5,47.0,19.3,14.9$ & Kedia et al. 2014b \\
\hline $\begin{array}{l}\text { Thymus kotschyanus Boiss. \& } \\
\text { Hohen. } \\
\text { Thymus daenensis Celak. } \\
\text { Stachys pubescens Ten. } \\
\text { Bupleurum falcatum L. }\end{array}$ & $\begin{array}{l}\text { Thymol } \\
\alpha \text {-terpineol, thymol, carvacrol } \\
\text { 2,6-octadiene, } \delta \text {-cadinene, } \\
\text { germacrene } \\
\text { Torilenol, spatulenol }\end{array}$ & $\begin{array}{l}46.7 \\
22.9,20.2,31.4 \\
11.5,19.7,22.4 \\
39.1,19.6\end{array}$ & $\begin{array}{l}\text { Mohammadi et al. } \\
2014\end{array}$ \\
\hline $\begin{array}{l}\text { Satureja hortensis L. } \\
\text { Origanum heracleoticum L. } \\
\text { Thymus vulgaris } \\
\text { Rosa } \times \text { damascena Herrm. } \\
\text { Pelargonium graveolens L'Hér. } \\
\text { Melaleuca alternifolia }\end{array}$ & $\begin{array}{l}\text { Carvacrol, Q-cimene } \\
\text { Carvacrol } \\
\text { Thymol, Q-cimene } \\
\text { Citronellol, geraniol } \\
\text { Citronellol, geraniol } \\
\text { Terpinen-4-ol, } \gamma \text {-terpinene }\end{array}$ & $\begin{array}{l}50.0,12.2 \\
75.8 \\
43.7,23.2 \\
51.3,25.8 \\
39.0,11.3 \\
40.7,17.8\end{array}$ & Stević et al. 2014 \\
\hline Laurus nobilis L. & Cinnamaldehyde, eugenol & $30.2,44.1$ & Xu et al. 2014 \\
\hline $\begin{array}{l}\text { Carum carvi L. } \\
\text { Coriandrum sativum L. } \\
\text { Mentha arvensis L. } \\
\text { Ocimum citriodorum Vis. } \\
\text { Origanum vulgare L. } \\
\text { Pimenta racemosa (Mill.) } \\
\text { J.W.Moore. } \\
\text { Thymus satureoides Coss. \& } \\
\text { Balansa. } \\
\text { Thymus vulgaris }\end{array}$ & $\begin{array}{l}\text { Carvone, limonene } \\
\text { Linalool } \\
\text { Menthol, menthon, } \\
\text { isomenthon } \\
\text { Geranial, neral, linalool } \\
\text { Carvacrol } \\
\text { Eugenol, myrcen } \\
\text { Borneol, thymol, carvacrol } \\
\text { Thymol, Q-cimene }\end{array}$ & $\begin{array}{l}68.7,21.5 \\
66.7 \\
42.1,21.7,13.6 \\
31.1,23.6,16.4 \\
86.9 \\
64.0,14.6 \\
29.8,12.0,10.0 \\
60.2,19.9\end{array}$ & Zabka et al. 2014 \\
\hline
\end{tabular}




\begin{tabular}{|c|c|c|c|}
\hline Plant species & EO main compounds & Relative percentage & Reference \\
\hline $\begin{array}{l}\text { Ruta angustifolia Pers. } \\
\text { Ruta chalepensis var. bracteosa } \\
\text { (DC.) Boiss. } \\
\text { Ruta graveolens L. }\end{array}$ & $\begin{array}{l}\text { 2-decanone, 2-undecanone } \\
\text { 2-nonanone, 1-nonene, } \\
\text { 2-undecanone } \\
\text { 2-nonanone, 2-undecanone }\end{array}$ & $\begin{array}{l}10.0,82.4 \\
32.7,13.9,32.5 \\
21.6,55.4\end{array}$ & $\begin{array}{l}\text { Haddouchi et al. } \\
2013\end{array}$ \\
\hline Cinnamomum zeylanicum & $\begin{array}{l}\text { 3-phenylpropionaldehyde, } \\
\text { trans-cinnamaldehyde }\end{array}$ & $10.4,80.4$ & Lu et al. 2013 \\
\hline Pelargonium graveolens & Citronellol, citronellyl formate & $41.5,10.8$ & \\
\hline Cuminum cyminum & $\begin{array}{l}\beta \text {-pinene, Q-cymene, } \\
\gamma \text {-terpinene, cuminaldehyde } \\
\text { Q-cimene, thymol }\end{array}$ & $14.0,16.8,11.3,46.9$ & \\
\hline Thymus vulgaris & Linalool, methyl chavicol & $37.6,39.7$ & \\
\hline Ocimum basilicum L. & Citronellal, citronellol, & $45.9,35.0$ & \\
\hline $\begin{array}{l}\text { Cymbopogon citratus (DC.) } \\
\text { Stapf. }\end{array}$ & geranial & $20.7,14.1,26.0$ & \\
\hline Melaleuca alternifolia & Terpinen-4-ol & 50.2 & Shao et al. 2013 \\
\hline Pulicaria mauritanica Batt. & Carvotanacetone & 87.3 & Znini et al. 2013 \\
\hline Eucalyptus tereticornis Sm. & $\alpha$-pinene, $\beta$-pinene, 1,8 -cineole & $22.5,22.5,19.8$ & Guleria et al. 2012 \\
\hline $\begin{array}{l}\text { Armoracia rusticana P.Gaertn., } \\
\text { B.Mey. \& Scherb. }\end{array}$ & $\begin{array}{l}\text { Allyl isothiocyanate, } \\
\beta \text {-phenylethyl isothiocyanate }\end{array}$ & $63.7,23.9$ & Kloucek et al. 2012 \\
\hline & $\begin{array}{l}\text { Diallyl disulfide, diallyl } \\
\text { trisulfide }\end{array}$ & $\begin{array}{l}43.8,27.1 \\
79.3\end{array}$ & \\
\hline $\begin{array}{l}\text { Allium sativum L. } \\
\text { Cinnamomum aromaticum Nees. } \\
\text { Origanum compactum Benth. }\end{array}$ & $\begin{array}{l}\text { trans-cinnamaldehyde } \\
\text { Carvacrol, thymol, Q-cimene }\end{array}$ & $28.4,20.2,17.9$ & \\
\hline Zataria multiflora Boiss. & Carvacrol & 76.1 & $\begin{array}{l}\text { Mahmoudi et al. } \\
2012\end{array}$ \\
\hline $\begin{array}{l}\text { Cicuta virosa var. latisecta } \\
\text { Celak. }\end{array}$ & $\begin{array}{l}\text { Q-cimene, } \gamma \text {-terpinene, } \\
\text { cuminaldehyde }\end{array}$ & $27.9,40.9,21.2$ & Tian et al. 2011a \\
\hline $\begin{array}{l}\text { Thymus vulgaris } \\
\text { Citrus aurantifolia (Christm.) } \\
\text { Swingle. }\end{array}$ & $\begin{array}{l}\gamma \text {-terpinene, Q-cimene } \\
\text { D-Limonene, } \beta \text {-pinene, } \\
\gamma \text {-terpinene }\end{array}$ & $\begin{array}{l}17.1,14.6 \\
45.1,20.5,10.5\end{array}$ & $\begin{array}{l}\text { Bosquez-Molina } \\
\text { et al. } 2010\end{array}$ \\
\hline $\begin{array}{l}\text { Verbena officinalis } \mathrm{L} . \\
\text { Thymus vulgaris } \\
\text { Origanum vulgare }\end{array}$ & $\begin{array}{l}\text { Isobornyl formate, (E)-citral } \\
\text { o-cimene, carvacrol } \\
\text { o-cimene, carvacrol }\end{array}$ & $\begin{array}{l}45.4,44.5 \\
56.2,24.4 \\
41.9,44.0\end{array}$ & Camele et al. 2010 \\
\hline Citrus maxima (Burm.) Merr. & $\begin{array}{l}\text { DL-Limonene, 1-hexene, } \\
\text { 4-Methy, Z-citral, E-citral }\end{array}$ & $31.8,15.2,13.3,17.7$ & Singh et al. 2010 \\
\hline Citrus sinensis (L.) Osbeck. & DL-Limonene & 90.66 & \\
\hline
\end{tabular}

Some compounds are present in several plant species in different concentrations. For example, carvacrol is present in four species: oregano $(O$. vulgare), $44.0 \%$ (Camele et al. 2010); Zataria (Zataria multiflora Boiss.), 76.1\% (Mahmoudi et al. 2012); summer savory (Satureja hortensis L.), 50.0\% (Stević et al. 2014), and avishan-e-denaii (Thymus daenensis Celak.), 31.4\% (Mohammadi et al. 2014); eugenol, in four species: clove (S. aromaticum), $82.3 \%$; cinnamon (C. zeylanicum), $12.8 \%$ (Manganyi et al. 2015); sweet bay (Laurus nobilis L.), 44.1\% (Xu et al. 2014); and bay rum tree (Pimenta racemosa (Mill.) J.W.Moore.), 64.0\% (Zabka et al. 2014); the geranial in three species: lipidia (Lippia rehmannii H.Pearson.), 34.5\% (Manganyi et al. 2015); basil sweet-lemon (Ocimum citriodorum Vis.), 31.1\% (Zabka et al. 2014), and lemongrass (Cymbopogon citratus (DC.) Stapf.), 26.0\% (Lu et al. 2013); finally, linalool, in two species: coriander (Coriandrum sativum L.), 66.7\% (Zabka et al. 2014), and sweet basil (Ocimum basilicum L.), 45.9\% (Lu et al. 2013). These compounds 
are secondary metabolites that occur in some plant species and serve as a defense against microorganisms. According to Sell (2009), few of them share the same biosynthetic pathways.

In other cases, the same component can vary in concentration between species of the same genus. The 2-undecanone level is $82.4 \%$ in mountain rue ( $R$. angustifolia), $55.4 \%$ in rue ( $R$. graveolens), and $32.5 \%$ in fringed rue (Ruta chalepensis var. bracteosa [DC.] Boiss.) (Haddouchi et al. 2013). Carvacrol represents 86.9\% in oregano (O. vulgare) (Zabka et al. 2014), 75.8\% in oregano (O. heracleoticum L.) (Stević et al. 2014), and $28.4 \%$ in sahtar (O. compactum Benth.) (Kloucek et al. 2012), whereas thymol can be quantified as $60.2 \%$ in thyme (T. vulgaris L.) (Zabka et al. 2014), but it can be $46.7 \%$ in other species such as T. kotschyanus Boiss. \& Hohen. (Mohammadi et al. 2014).

There are also variations in the concentration of the same compound in the same species, for example, thymol in T. vulgaris, with 35.6 to $60.2 \%$ (Pekmezovic et al. 2015; Zabka et al. 2014), carvacrol in O. vulgare, 44.0 to $86.9 \%$ (Camele et al. 2010; Zabka et al. 2014), and terpinen-4-ol in tea tree (Melaleuca alternifolia [Maiden \& Betche] Cheel.), with 31.1 to 50.2\% (Shao et al. 2013; Stević et al. 2014; Zhang et al. 2018). According to Schmidt (2009), the content of EOs components may depend on several factors, including the organ of the plant used, environmental conditions, and the stress to which the botanical species was subjected during its development in the field.

\section{Potential of EOS for controlling PHYTOPATHOGENIC FUNGI}

EOs have been tested for the control of phytopathogenic fungi in in vitro and in vivo studies. The literature reports that the effectiveness of EOs varied depending on the plant species, microorganism, EO concentration, and the evaluation technique used, among other factors.

\section{TeChNiQues to eVAluate THE EFFECTIVENESS OF THE EOS ON FUNGAL DEVELOPMENT}

Two techniques are used to evaluate the effectiveness of EOs. The first is through direct contact, in which case, the EO is mixed with the culture medium, either solid or liquid (in vitro studies), or placed directly on the fruit (in vivo studies). The second is through vapor phase, where the EO is impregnated in an absorbent element, and then it is volatilized flooding the environment where the fungus has been placed (Petri dish for in vitro studies and hermetic containers for in vivo studies).

Thus, the same technique can have different names. When it involves direct contact in the solid medium it is known as toxic medium assay (Manganyi et al. 2015), poisoned medium technique (Chen et al. 2014), dilution in agar method (Hamdani and Allem 2015), radial growth inhibition technique (Badawy and Abdelgaleil 2014), and agar well diffusion method (Ray et al. 2018). Other methods reported in vitro are direct contact in the liquid medium, micro, and macro dilution in broth (Juliano et al. 2019; Khosravi et al. 2015; Martins et al. 2013), and in the vapor phase, disc diffusion (Kloucek et al. 2012; Rguez et al. 2019; Zhang et al. 2018), drop diffusion test (Saroj et al. 2015), and soaked cotton (Mahmoudi et al. 2012).

In in vivo studies, the following techniques have been reported: by direct contact and aspersion (Camele et al. 2010), by immersion (Bosquez-Molina et al. 2010), in the vapor phase, soaked cotton (Kedia et al. 2014b), sterile paper discs (Stević et al. 2014), and drop (Mehra et al. 2013).

To evaluate the effectiveness of EOs, we used the minimum inhibitory concentration (MIC), which is defined as the lowest EO concentration that completely inhibits the growth of the phytopathogenic fungus -a synonym used for this is 'the minimum inhibitory amount' (MIA) (Guleria et al. 2012, Van de Vel et al. 2019). The minimum fungicidal concentration (MFC), defined as the lowest concentration, resulted in zero fungus growth when it is cultivated again in a culture medium - and a synonym for it could be 'the minimum lethal concentration' (MLC) (Martins et al. 2013).

\section{EOS IN THE CONTROL OF PHYTOPATHOGENIC FUNGI IN VITRO}

Table 2 presents a series of studies in which EOs obtained from 54 plant species were effective in controlling 60 species of phytopathogenic fungi. The genera with the highest number of species were: Citrus (Bosquez-Molina et al. 2010; Dimić et al. 2014; 
Singh et al. 2010), and Ruta, both from the Rutaceae family (Haddouchi et al. 2013) with four species each, the genera Cinnamomum (Lauraceae family) (Kloucek et al. 2012; Manganyi et al. 2015; Pekmezovic et al. 2015), Ocimum (Costa et al. 2015; Lu et al. 2013; Zabka et al. 2014), and Thymus (Lamiaceae family) (Camele et al. 2010; Mohammadi et al. 2014; Zabka et al. 2014), with three species each, and the genera Pelargonium (Geraniaceae family) (Lu et al. 2013; Matusinsky et al. 2015), Mentha (Kedia et al. 2014a; Lu et al. 2013), Origanum (Lamiaceae family) (Stević et al. 2014; Zabka et al. 2014), Helichrysum (Asteraceae family) (Juliano et al. 2019; Ray et al. 2018), and Salvia (Lamiaceae family) (Elshafie et al. 2018; Rguez et al. 2019), with two species each.

Botanical species with the greatest capacity reported for in vitro fungi control were dill (Apium graveolens L.) against Sclerotinia sclerotiorum (Lib.) de Bary. in $0.12 \mu \mathrm{L} \mathrm{mL}{ }^{-1}$ doses (Ma et al. 2015a); oregano (O. vulgare) against Aspergillus flavus Link., and A. niger P.E.L. van Tieghem. (de Sousa et al. 2013), and verbena (Verbena officinalis L.), thyme (T. vulgaris), and oregano (O. vulgare) for Botrytis cinerea Pers., Penicillium italicum Wehmer., and Phytophthora citrophthora R.\&E. Sm. Control (0.25 $\left.\mu \mathrm{L} \mathrm{mL}^{-1}\right)$ (Camele et al. 2010).

They are followed by tea tree EOs (M. alternifolia) against B. cinerea, $0.4 \mu \mathrm{L} \mathrm{mL}^{-1}$ dose (Shao et al. 2013), basil (O. selloi) against Moniliophthora perniciosa (Stahel) Aime \& Phillips-Mora. (Costa et al. 2015), thyme (T. vulgaris), clove (S. aromaticum), and cinnamon (C. zeylanicum) against Fusarium oxysporum Schlecht. (Manganyi et al. 2015), and everlasting (Helichrysum splendidum [Thunb.] Less.) against Colletotrichum gloeosporioides (Penz.) Penz. \& Sacc. in $0.5 \mu \mathrm{L} \mathrm{mL}^{-1}$ doses (Mashigo et al. 2015). The $\mathrm{EO}$ of cumin (C. cyminum) against $A$. flavus, $0.6 \mu \mathrm{L} \mathrm{mL}^{-1}$ doses (Kedia et al. 2014b), grapefruit (Citrus maxima (Burm.) Merr.), and orange (C. sinensis) against the same microorganism in 0.75 $\mu \mathrm{L} \mathrm{mL}{ }^{-1}$ doses (Singh et al. 2010), and Mexican lemon (C. aurantifolia (Christm.) Swingle.), and thyme (T. vulgaris) against $C$. gloeosporioides in $0.85 \mu \mathrm{L} \mathrm{mL}^{-1}$ doses (Bosquez-Molina et al. 2010).

Finally, effective EOs that are reported at concentrations of less than $1 \mu \mathrm{L} \mathrm{mL}^{-1}$ were peppermint ( $M$. spicata) against $A$. flavus (Kedia et al. 2014a), rosemary (Rosmarinus officinalis L.) against $A$. flavus and $A$. niger (de Sousa et al. 2013), mint geranium (Pelargonium odo- ratissimum (L.) L'Hér.), and thyme (T. vulgaris) against Oculimacula yallundae (Walker \& Spooner) Crous \& Gams., Zymoseptoria tritici (Desm.) Quaedvlieg \& Crous., and Pyrenophora teres Drechsler. (Matusinsky et al. 2015), and caraway (Carum carvi L.), lemon basil (O. citriodorum), oregano (O. vulgare), malagueta ( $P$. tolonif), Moroccan thyme (Thymus satureoides Coss. \& Balansa.), and thyme (T. vulgaris) against A. niger, Cladosporium cladosporioides (Fresen.) G.A. de Vries., and Stachybotrys chartarum (Ehrenb.) S. Hughes. (Zabka et al. 2014).

\section{EOS IN THE CONTROL OF PHYTOPATHOGENIC FUNGI IN VIVO}

Overall, the reported EO with the lowest effective dose $\left(0.50 \mu \mathrm{L} \mathrm{mL}^{-1}\right)$ was dill (A. graveolens) for the control of white rot (S. sclerotiorum) in artificially inoculated leaves of turnip (Brassica napus L.). When the EO was sprayed before inoculation, the development of the pathogen was inhibited. At the same time, in the control treatment, lesions reached up to $30.2 \mathrm{~mm}$ in diameter (Ma et al. 2015a) (Table 2).

In the vapor phase, the cumin EO (C. cyminum) with a $0.6 \mu \mathrm{L}$ mL-1 dose, for the control of A. flavus in wheat seeds (Triticum aestivum L.) and chickpea (Cicer arietinum L.), with about $65.1 \%$ and $50.0 \%$, respectively after 12 months of storage (Kedia et al. 2014b). Likewise, A. flavus and A. niger fungi of the table grapes (Vitis labrusca L.) were inhibited for 12 and 24 days, by immersion in rosemary EO $(R$. officinalis) at $1 \mu \mathrm{L} \mathrm{mL}{ }^{-1}$ concentration when stored at room temperature $\left(25^{\circ} \mathrm{C}\right.$ ) and $12^{\circ} \mathrm{C}$, respectively (de Sousa et al. 2013).

In papaya fruit (Carica papaya L.), thyme EO ( $T$. vulgaris) was effective for the control of anthracnose disease (C. gloeosporioides) employing an immersion treatment of $1.5 \mu \mathrm{L} \mathrm{mL}^{-1}$. When the EO was applied after inoculation, the inhibition was $100 \%$. In contrast, if the treatment was applied after inoculation, a 50\% inhibition was achieved (Bosquez-Molina et al. 2010).

The application by sprinkling of $2 \mu \mathrm{L} \mathrm{mL} \mathrm{L}^{-1}$ of thyme EO (T. vulgaris) in orange fruits (C. sinensis) for controlling gray mold (B. cinerea), phytophthora (P. citrophthora), and rhizopus rot (Rhizopus tolonifera (Ehrenb.) Vuill.) was 100\% effective (Camele et al. 2010). 
Table 2. Plant species and EOs doses applied for in vitro and in vivo control of various phytopathogenic fungi.

\begin{tabular}{|c|c|c|c|c|}
\hline Plant species & Phytopathogenic fungi & Evaluation & EO dose & Reference \\
\hline Solidago canadensis & $\begin{array}{l}\text { Monilinia fructicola (G. Winter) } \\
\text { Honey. }\end{array}$ & In vitro & $\begin{array}{l}1000 \mu \mathrm{g} \\
\mathrm{mL}^{-1}\end{array}$ & $\begin{array}{l}\text { Elshafie et al. } \\
2019\end{array}$ \\
\hline $\begin{array}{l}\text { Helichrysum } \\
\text { microphyllum subsp. } \\
\text { tyrrhenicum }\end{array}$ & $\begin{array}{l}\text { Aspergillus brasiliensis Varga, } \\
\text { Frisvad \& Samson }\end{array}$ & In vitro & $2.00 \mathrm{mg} \mathrm{mL}^{-1}$ & $\begin{array}{l}\text { Juliano et al. } \\
2019\end{array}$ \\
\hline Salvia officinalis & $\begin{array}{l}\text { Botrytis cinerea Pers., Fusarium } \\
\text { sambucinum Fuckel. }\end{array}$ & In vitro & $1.93 \mu \mathrm{g} \mathrm{mL} \mathrm{L}^{-1}$ & $\begin{array}{l}\text { Rguez et al. } \\
2019\end{array}$ \\
\hline Rabdosia rugosus & $\begin{array}{l}\text { Rhizoctonia solani J.G. Kühn., } \\
\text { Sclerotium rolfsii Sacc., Fusarium } \\
\text { oxysporum Schlecht. }\end{array}$ & In vitro & $250 \mathrm{ppm}$ & $\begin{array}{l}\text { Singh et al. } \\
2019\end{array}$ \\
\hline Salvia hispanica & $\begin{array}{l}\text { Monilinia laxa (Aderh. y Ruhl.), } \\
\text { M. fructicola, M. fructigena (Aderh. } \\
\text { \& Ruhland) Honey., Aspergillus } \\
\text { fumigatus Fresen., Penicillium } \\
\text { digitatum (Pers.) Sacc., P. expansum } \\
\text { Link. }\end{array}$ & In vitro & $40 \%$ & $\begin{array}{l}\text { Elshafie et al. } \\
2018\end{array}$ \\
\hline Hedychium coronarium & $\begin{array}{l}\text { Aspergillus niger P.E.L., A. flavus } \\
\text { Link., Fusarium oxysporum }\end{array}$ & In vitro & $6.25 \mu \mathrm{g} \mathrm{mL} \mathrm{L}^{-1}$ & Ray et al. 2018 \\
\hline Melaleuca alternifolia & $\begin{array}{l}\text { Penicillium italicum Wehmer., } P . \\
\text { digitatum }\end{array}$ & In vitro & $12 \mathrm{mg} \mathrm{mL}^{-1}$ & $\begin{array}{l}\text { Zhang et al. } \\
2018\end{array}$ \\
\hline Helichrysum italicum & $\begin{array}{l}\text { Fusarium solani var. coeruleum (Lib. } \\
\text { ex Sacc.) C. Booth., Aspergillus } \\
\text { niger, Ascochyta rabiei (Pass.) Labr. }\end{array}$ & In vitro & $50.6 \mu \mathrm{g} \mathrm{mL} L^{-1}$ & $\begin{array}{l}\text { Djihane et al. } \\
2017\end{array}$ \\
\hline Ocimum selloi & $\begin{array}{l}\text { Moniliophthora perniciosa (Stahel) } \\
\text { Aime \& Phillips-Mora. }\end{array}$ & In vitro & 500 ppm & $\begin{array}{l}\text { Costa et al. } \\
2015\end{array}$ \\
\hline $\begin{array}{l}\text { Lippia adoensis var. } \\
\text { koseret Sebsebe. }\end{array}$ & $\begin{array}{l}\text { Aspergillus flavus, A. parasiticus } \\
\text { Speare., A. niger, A. fumigatus }\end{array}$ & In vitro & $2 \mu \mathrm{L} \mathrm{mL}-1$ & $\begin{array}{l}\text { Gemeda et al. } \\
2015\end{array}$ \\
\hline Anethum graveolens & $\begin{array}{l}\text { Sclerotinia sclerotiorum (Lib.) de } \\
\text { Bary. }\end{array}$ & $\begin{array}{l}\text { In vitro } \\
\text { In vivo } \\
\text { (turnip) }\end{array}$ & $\begin{array}{l}\text { Medium - } \\
1.0 \mu \mathrm{L} \mathrm{mL}^{-1} \\
\text { Air }-0.125 \\
\mu \mathrm{L} \mathrm{mL}^{-1} \\
0.50 \mu \mathrm{L} \mathrm{mL} \mathrm{m}^{-1}\end{array}$ & Ma et al. 2015a \\
\hline $\begin{array}{l}\text { Thymus vulgaris } \\
\text { Syzigium aromaticum } \\
\text { Cinnamomum zeylanicum }\end{array}$ & Fusarium oxysporum & In vitro & $500 \mu \mathrm{L} \mathrm{L}^{-1}$ & $\begin{array}{l}\text { Manganyi et } \\
\text { al. } 2015\end{array}$ \\
\hline $\begin{array}{l}\text { Helichrysum splendidum } \\
\text { (Thunb.) Less. }\end{array}$ & $\begin{array}{l}\text { Colletotrichum gloeosporioides (Penz.) } \\
\text { Penz. \& Sacc. }\end{array}$ & In vitro & $500 \mu \mathrm{L} \mathrm{L}^{-1}$ & $\begin{array}{l}\text { Mashigo et al. } \\
2015\end{array}$ \\
\hline $\begin{array}{l}\text { Thymus vulgaris } \\
\text { Pelargonium } \\
\text { odoratissimum }\end{array}$ & $\begin{array}{l}\text { Oculimacula yallundae (Walker \& } \\
\text { Spooner) Crous \& Gams. } \\
\text { (Desm.) Quaedvlieg \& Crous. } \\
\text { Pyrenophora teres Drechsler. }\end{array}$ & In vitro & $1.0 \mu \mathrm{L} \mathrm{mL}^{-1}$ & $\begin{array}{l}\text { Matusinsky et } \\
\text { al. } 2015\end{array}$ \\
\hline $\begin{array}{l}\text { Thymus vulgaris } \\
\text { Cinnamomum cassia }\end{array}$ & Aspergillus flavus & In vitro & $\begin{array}{l}31.2 \mu \mathrm{g} \mathrm{mL}^{-1} \\
62.5 \mu \mathrm{g} \mathrm{mL}-1\end{array}$ & $\begin{array}{l}\text { Pekmezovic et } \\
\text { al. } 2015\end{array}$ \\
\hline $\begin{array}{l}\text { Anthemis odontostephana } \\
\text { var. odontostephana }\end{array}$ & $\begin{array}{l}\text { Aspergillus niger } \\
\text { Fusarium solani (Mart.) Sacc. }\end{array}$ & In vitro & $32.6 \mu \mathrm{g} \mathrm{mL} \mathrm{L}^{-1}$ & $\begin{array}{l}\text { Zebarjad and } \\
\text { Farjam } 2015\end{array}$ \\
\hline
\end{tabular}




\begin{tabular}{|c|c|c|c|c|}
\hline Plant species & Phytopathogenic fungi & Evaluation & EO dose & Reference \\
\hline Citrus limon (L.) Osbeck. & $\begin{array}{l}\text { Aspergillus parasiticus, A. carbonarius } \\
\text { (Bainier) Thom. } \\
\text { Cladosporium cladosporioides } \\
\text { (Fresen.) G.A. de Vries. } \\
\text { Eurotium herbariorum (F.H. Wigg.) } \\
\text { Link. } \\
\text { Penicillium chrysogenum Thom. }\end{array}$ & In vitro & $2.5 \mu \mathrm{L} \mathrm{mL}^{-1}$ & $\begin{array}{l}\text { Dimić et al. } \\
2014\end{array}$ \\
\hline Mentha spicata & $\begin{array}{l}\text { Absidia ramosa (Zopf) Lendn. } \\
\text { Aspergillus flavus, A. fumigatus, } \\
\text { A. glaucus (L.) Link., A. niger, A. } \\
\text { unguis (Émile-Weill \& L. Gaudin) } \\
\text { Dodge. } \\
\text { Cladosporium cladosporioides } \\
\text { Curvularia lunata (Wakker) Boedijn. } \\
\text { Fusarium oxysporum } \\
\text { Mycelia sterilia } \\
\text { Penicillium citrinum Thom., P. } \\
\text { italicum, P. luteum Zukal., P. } \\
\text { purpurogenum Stoll. } \\
\text { Rhizopus stolonifer (Ehrenb.) Vuill. } \\
\text { Spondylocladium australe J.C. } \\
\text { Gilman \& E.V. Abbott. }\end{array}$ & In vitro & $1.0 \mu \mathrm{L} \mathrm{mL}^{-1}$ & $\begin{array}{l}\text { Kedia et al. } \\
\text { 2014a }\end{array}$ \\
\hline Cuminum cyminum & $\begin{array}{l}\text { Absidia ramosa } \\
\text { Aspergillus flavus, A. fumigatus, A. } \\
\text { glaucus, A. niger, A. unguis } \\
\text { Cladosporium cladosporioides } \\
\text { Curvularia lunata } \\
\text { Fusarium oxysporum } \\
\text { Mycelia sterilia } \\
\text { Penicillium citrinum, P. italicum, P. } \\
\text { luteum, P. purpurogenum } \\
\text { Rhizopus stolonifer } \\
\text { Spondylocladium australe }\end{array}$ & $\begin{array}{l}\text { In vitro } \\
\text { In vivo } \\
\text { (wheat and } \\
\text { chickpea) }\end{array}$ & $0.6 \mu \mathrm{L} \mathrm{mL}^{-1}$ & $\begin{array}{l}\text { Kedia et al. } \\
2014 b\end{array}$ \\
\hline $\begin{array}{l}\text { Thymus kotschyanus } \\
\text { Stachys pubescens }\end{array}$ & $\begin{array}{l}\text { Fusarium oxysporum } \\
\text { Aspergillus flavus }\end{array}$ & In vitro & $0.5 \mu \mathrm{g} \mathrm{mL} L^{-1}$ & $\begin{array}{l}\text { Mohammadi et } \\
\text { al. } 2014\end{array}$ \\
\hline $\begin{array}{l}\text { Pinus nigra subsp. } \\
\text { pallasiana (Lamb.) } \\
\text { Holmboe. } \\
\text { Pinus nigra var. banatica } \\
\text { Georgescu \& Ionescu }\end{array}$ & Aspergillus niger & In vitro & $5 \mathrm{mg} \mathrm{mL}^{-1}$ & $\begin{array}{l}\text { Šarac et al. } \\
2014\end{array}$ \\
\hline $\begin{array}{l}\text { Satureja hortensis } \\
\text { Origanum heracleoticum } \\
\text { Thymus vulgaris } \\
\text { Rosa } \times \text { damascena }\end{array}$ & $\begin{array}{l}\text { Fusarium subglutinans (Wollenw. \& } \\
\text { Reinking) P.E. Nelson, Toussoun } \\
\text { \& Marasas., F. solani, F. tricinctum } \\
\text { (Corda) Sacc., F. sporotrichioides } \\
\text { Sherb., F. verticillioides (Sacc.) } \\
\text { Nirenberg., F. oxysporum, F. } \\
\text { semitectum Berk. \& Ravenel., F. } \\
\text { equiseti (Corda) Sacc. } \\
\text { Aspergillus flavus, A. niger } \\
\text { Gliocladium roseum Bainier. } \\
\text { Curvularia lunata }\end{array}$ & In vitro & $\begin{array}{l}0.07 \text { a } 0.9 \\
\mathrm{mg} \mathrm{mL}^{-1}\end{array}$ & $\begin{array}{l}\text { Stević et al. } \\
2014\end{array}$ \\
\hline
\end{tabular}




\begin{tabular}{|c|c|c|c|c|}
\hline Plant species & Phytopathogenic fungi & Evaluation & EO dose & Reference \\
\hline $\begin{array}{l}\text { Satureja hortensis } \\
\text { Origanum heracleoticum } \\
\text { Thymus vulgaris } \\
\text { Rosa } \times \text { damascena }\end{array}$ & $\begin{array}{l}\text { Verticillium dahliae Kleb. } \\
\text { Trichoderma viride Pers., T. roseum } \\
\text { Pers. } \\
\text { Myrothecium verrucaria (Alb. \& } \\
\text { Schwein.) Ditmar. }\end{array}$ & In vitro & $\begin{array}{l}0.07 \text { a } 0.9 \\
\mathrm{mg} \mathrm{mL}^{-1}\end{array}$ & $\begin{array}{l}\text { Stević et al. } \\
2014\end{array}$ \\
\hline $\begin{array}{l}\text { Carum carvi } \\
\text { Ocimum citriodorum } \\
\text { Origanum vulgare } \\
\text { Pimenta racemosa } \\
\text { Thymus satureoides } \\
\text { Thymus vulgaris }\end{array}$ & $\begin{array}{l}\text { Stachybotrys chartarum (Ehrenb.) S. } \\
\text { Hughes. } \\
\text { Cladosporium cladosporioides } \\
\text { Aspergillus niger }\end{array}$ & In vitro & $1.0 \mu \mathrm{L} \mathrm{mL}^{-1}$ & $\begin{array}{l}\text { Zabka et al. } \\
2014\end{array}$ \\
\hline $\begin{array}{l}\text { Origanum vulgare } \\
\text { Rosmarinus officinalis }\end{array}$ & Aspergillus niger, A. flavus & $\begin{array}{l}\text { In vitro } \\
\text { In vivo } \\
\text { (grapes) }\end{array}$ & $\begin{array}{l}0.25 \mu \mathrm{L} \mathrm{mL}^{-1} \\
1.0 \mu \mathrm{L} \mathrm{mL}^{-1}\end{array}$ & $\begin{array}{l}\text { de Sousa et al. } \\
2013\end{array}$ \\
\hline $\begin{array}{l}\text { Ruta angustifolia } \\
\text { Ruta chalepensis var. } \\
\text { bracteosa } \\
\text { Ruta graveolens } \\
\text { Ruta tuberculate Forssk. }\end{array}$ & $\begin{array}{l}\text { Aspergillus fumigatus, A. flavus } \\
\text { Cladosporium herbarum (Pers.) Link. } \\
\text { Fusarium oxysporum }\end{array}$ & In vitro & $10 \mu \mathrm{L}$ disk & $\begin{array}{l}\text { Haddouchi et } \\
\text { al. } 2013\end{array}$ \\
\hline $\begin{array}{l}\text { Cinnamomum zeylanicum } \\
\text { Thymus vulgaris } \\
\text { Ocimum basilicum } \\
\text { Cuminum cyminum } \\
\text { Pelargonium graveolens } \\
\text { Cymbopogon citratus } \\
\text { Litsea cubeba (Lour.) } \\
\text { Pers. } \\
\text { Mentha arvensis }\end{array}$ & $\begin{array}{l}\text { Colletotrichum destructivum O'Gara. } \\
\text { Phytophthora parasitica var. } \\
\text { nicotianae (Breda de Haan) Tucker. }\end{array}$ & In vitro & $240 \mu \mathrm{g} \mathrm{mL} L^{-1}$ & Lu et al. 2013 \\
\hline Eucalyptus globulus & $\begin{array}{l}\text { Mucor hiemalis Wehmer. } \\
\text { Penicillium glabrum (Wehmer) } \\
\text { Westling. } \\
\text { Fusarium roseum Link. }\end{array}$ & In vitro & $\begin{array}{l}1.5 \text { a } 5.0 \mu \mathrm{L} \\
\mathrm{mL}^{-1}\end{array}$ & $\begin{array}{l}\text { Martins et al. } \\
2013\end{array}$ \\
\hline Melaleuca alternifolia & Botrytis cinerea & In vitro & $\begin{array}{l}0.4 \text { a } 1.0 \mathrm{~mL} \\
\mathrm{l}^{-1}\end{array}$ & Shao et al. 2013 \\
\hline Pulicaria mauritanica & Penicillium expansum & In vitro & $2.0 \mu \mathrm{L} \mathrm{mL}^{-1}$ & $\begin{array}{l}\text { Znini et al. } \\
2013\end{array}$ \\
\hline $\begin{array}{l}\text { Armoracia rusticana } \\
\text { Allium sativum } \\
\text { Cinnamomum } \\
\text { aromaticum }\end{array}$ & $\begin{array}{l}\text { Aspergillus niger } \\
\text { Penicillium digitatum }\end{array}$ & In vitro & $\begin{array}{l}31.2 \mu \mathrm{L} \mathrm{L}^{-1} \\
62.5 \mu \mathrm{L} \mathrm{L}^{-1}\end{array}$ & $\begin{array}{l}\text { Kloucek et al. } \\
2012\end{array}$ \\
\hline Citri-V & $\begin{array}{l}\text { Penicillium chrysogenum } \\
\text { Aspergillus niger }\end{array}$ & $\begin{array}{l}\text { In vitro } \\
\text { In vivo } \\
\text { (Tomato) }\end{array}$ & $\begin{array}{l}\text { Air - } 15 \mathrm{mg} \\
\mathrm{L}^{-1}\end{array}$ & $\begin{array}{l}\text { Phillips et al. } \\
2012\end{array}$ \\
\hline $\begin{array}{l}\text { Mazus goodenifolius } \\
\text { (Hornem.) Pennell. }\end{array}$ & Rhizopus solani & In vitro & $20 \mathrm{mg} \mathrm{mL}^{-1}$ & Riaz et al. 2012 \\
\hline $\begin{array}{l}\text { Cicuta virosa var. } \\
\text { latisecta }\end{array}$ & $\begin{array}{l}\text { Aspergillus flavus, A. oryzae (Ahlb.) } \\
\text { Cohn., A. niger }\end{array}$ & $\begin{array}{l}\text { In vitro } \\
\text { In vivo } \\
\text { (Cherry } \\
\text { tomato) }\end{array}$ & $\begin{array}{l}5 \mu \mathrm{L} \mathrm{mL} \mathrm{L}^{-1} \\
200 \mu \mathrm{LL} \mathrm{mL}^{-1}\end{array}$ & $\begin{array}{l}\text { Tian et al. } \\
\text { 2011a }\end{array}$ \\
\hline
\end{tabular}




\begin{tabular}{|c|c|c|c|c|}
\hline Plant species & Phytopathogenic fungi & Evaluation & EO dose & Reference \\
\hline Anethum graveolens & $\begin{array}{l}\text { Aspergillus flavus, A. oryzae, } \\
\text { A. niger }\end{array}$ & $\begin{array}{l}\text { In vitro } \\
\text { In vivo } \\
\text { (Cherry } \\
\text { tomato) }\end{array}$ & $\begin{array}{l}2.0 \mu \mathrm{L} \mathrm{mL}^{-1} \\
120 \mu \mathrm{mL}^{-1}\end{array}$ & $\begin{array}{l}\text { Tian et al. } \\
2011 b\end{array}$ \\
\hline $\begin{array}{l}\text { Thymus vulgaris } \\
\text { Citrus aurantifolia }\end{array}$ & Colletotrichum gloeosporioides & $\begin{array}{l}\text { In vitro } \\
\text { In vivo } \\
\text { (papaya) }\end{array}$ & $\begin{array}{l}0.085 \% \\
(\mathrm{v} / \mathrm{w}) \\
0.15 \%(\mathrm{v} / \mathrm{w})\end{array}$ & $\begin{array}{l}\text { Bosquez- } \\
\text { Molina et al. } \\
2010\end{array}$ \\
\hline $\begin{array}{l}\text { Origanum vulgare } \\
\text { Verbena officinalis } \\
\text { Thymus vulgaris }\end{array}$ & $\begin{array}{l}\text { Botrytis cinerea } \\
\text { Penicillium italicum } \\
\text { Phytophthora citrophthora R.\&E. Sm. } \\
\text { Rhizopus stolonifer }\end{array}$ & $\begin{array}{l}\text { In vitro } \\
\text { In vivo } \\
\text { (orange) }\end{array}$ & $\begin{array}{l}250 \mathrm{ppm} \\
2000 \mathrm{ppm}\end{array}$ & $\begin{array}{l}\text { Camele et al. } \\
2010\end{array}$ \\
\hline $\begin{array}{l}\text { Citrus maxima } \\
\text { Citrus sinensis }\end{array}$ & Aspergillus flavus & In vitro & $750 \mathrm{ppm}$ & $\begin{array}{l}\text { Singh et al. } \\
2010\end{array}$ \\
\hline
\end{tabular}

Does not include the species Alternaria alternata. Citri-V = 50:50 mix of orange and bergamot essential oil.

\section{MECHANisms OF ACTION OF EOs ON PHYTOPATHOGENIC FUNGI}

The action mechanism of the EOs on fungi is not entirely known. However, Rivera et al. (2015) proposed that the antimicrobial action is attributed to their ability to penetrate through the cell membranes and inhibit the functional properties of the cell by causing severe damage to organelles. There are different microscopy techniques used to observe these physical alterations. Overall, the Optical Microscopy and Scanning Electron Microscopy (SEM) are used to recognize the morphological changes in fungi. In contrast, the Transmission Electron Microscopy (TEM) is used to look into cellular alterations.

It is generally reported in the literature that, in control treatments, the fungi presented mycelium with regular morphology, healthy development, abundant conidia, and round hyphae with smooth external surfaces, constant diameter, and integral membranes. On the contrary, in EOs-treated fungi, it was possible to observe different morphological alterations and structural damage, which increased depending on the concentration.

For example, the application of the cinnamon EO (C. zeylanicum) in Alternaria alternata (Fr.) Keissl., produce alterations in its hyphae collapse, crushing, emptying, and lysis of the cell wall, and with aggregates of wrinkled hyphae (Lu et al. 2013). In other studies, thyme $\mathrm{EO}$ (T. vulgaris) affected the conidia germination (and in some cases, the total absence of these) together with a delay in the development of the germinative tube, rupture of the cell wall and the conidia plasma membrane, with disorganization of the cytoplasm and destruction of organelles (Perina et al. 2014), while citronella EO (Cymbopogon nardus (L.) Rendle.) affected the mycelial morphology with empty, folded, and flattened hyphae, with a rough and deformed surface, with the absence of conidia (Chen et al. 2014).

In the same fungus, with laurel EO (L. nobilis), the mycelium was degraded with folds and wrinkles on the cell walls surface and few visible spores (Xu et al. 2014). Za'atar EO (Z. multiflora) is reported to cause the granulation of cytoplasm, inhibition of mycelial growth, decrease and loss in the conidia formation, inhibition of conidial germination and shortening of the germinative tubes, as well as, a reduction in the diameter of hyphae (with sub-apical germination and with anomalous bulbous structures at its tips), collapse and wrinkling of hyphae and production of chlamydoconidia in old hyphae (Mahmoudi et al. 2012).

In other phytopathogenic fungi, the damages observed were similar. For example, A. flavus incubated in peppermint EO (M. spicata), presented hyphae distorted with collapsed conidia and depressions in the surface. Also, through TEM observations, plasma membrane rupture, leakage of cellular material, and decrease of the cellular matrix (Kedia et al. 2015) were documented, while $A$. niger treated with dill EO ( $A$. graveolens) showed deformation of the conidia, with 
severe damage, rupture and loss of integrity in these structures, as well as, craters in the vesicles, aggregates of wrinkled hyphae, decrease in diameter, collapse and flattening (Tian et al. 2011b).

In $B$. cinerea, tea tree EO (M. alternifolia) inhibited fungal growth and spore germination, and empty, collapsed, flat hyphae also occurred. Observations by TEM showed that the cell wall was destroyed. Therefore, the cell membrane permeability increased, in addition to cytoplasm coagulation by a higher density of electrons, increased mitochondrial volume, and loss of organelles (Shao et al. 2013).

In Colletotrichum destructioum O'Gara., thyme EO (T. vulgaris) caused considerable mycelium damage as aggregates of wrinkled, collapsed, crushed, and empty hyphae, and cinnamon EO (C. zeylanicum) on Phytophthora parasitica var. nicotianae (Breda de Haan) Tucker. caused alterations similar to those mentioned for C. destructivum (Lu et al. 2013).

\section{USE OF EOS AS COMPONENTS OF COATINGS AND BIOACTIVE FILMS FOR CONTROLLING PHYTOPATHOGENIC FUNGI}

On the issue of antimicrobial substances, EOs are useful for controlling phytopathogenic fungi. However, their direct application in food brings about some problems: rapid volatility, aroma transfer, and toxicity. For this reason, its use has been studied in films and coatings, which allows them to minimize application doses; also, their gradual migration from the matrix allows their release to be scheduled (Ouattara et al. 2000; Sánchez-González et al. 2011).
On the use of biodegradable polymers for the development of coatings and edible films to which EOs were added and which were later evaluated in the control of phytopathogenic fungi (Table 3), it was found that $47.3 \%$ of the works focused on the development of coatings (Guerra et al. 2015; Vu et al. 2011), and an equal percentage on film development (47.3\%) (Avila-Sosa et al. 2010; Hemalatha et al. 2017; Pola et al. 2016).

The EOs most used in the formulations were those from oregano (O. vulgare) (Barreto et al. 2016; Raphaël and Meimandipour 2017), and thyme (T. vulgaris) (Bill et al. 2014; Yahyaoui et al. 2016), followed by lemongrass (C. citratus) (Avila-Sosa et al. 2012; Ben-Fadhel et al. 2017), and cinnamon (C. zeylanicum) (Mateo et al. 2017; Noshirvani et al. 2017). As for phytopathogenic fungi, the most evaluated were $A$. niger (12 cases) (Barreto et al. 2016, Ben-Fadhel et al. 2017, Hemalatha et al. 2017), followed by $R$. tolonifera (Pola et al. 2016; Ramos-García et al. 2012), and Penicillium expansum Link. (Gniewosz et al. 2013; Guerra et al. 2016).

The studied model varied between coatings and films. On coatings, evaluations were conducted on cherry tomato (Solanum lycopersicum var. cerasiforme (Dunal) D.M. Spooner, G.J. Anderson \& R.K. Jansen.) (Barreto et al. 2016), grape (V. labrusca) (dos Santos et al. 2012), tomato (S. lycopersicum L.) (Ramos-García et al. 2012), broccoli (Brassica oleracea var. Itálica Plenck.) (Ben-Fadhel et al. 2017), avocado (Persea americana Mill.) (Bill et al. 2014), and strawberry (Fragaria $\times$ ananassa (Duchesne ex Weston) Duchesne ex Rozier.) (Vu et al. 2011). On the other hand, $88.8 \%$ of the work with films was carried out in vitro and a few in carrots (Daucus carota L.) (Gniewosz et al. 2013).

Table 3. Biodegradable polymers added with EOs for the development of coatings and films, and their evaluation on phytopathogenic fungi.

\begin{tabular}{|c|c|c|c|c|c|}
\hline Polymeric matrix & EOs & Type & Phytopathogenic fungi & Assay & Reference \\
\hline $\begin{array}{l}\text { Alginate }(1.3 \mathrm{~g}) \\
\text { Glycerol }(1.6 \%) \\
\text { Sodium diacetate }(0.5 \%) \\
\text { Natamycin }(0.008 \%) \\
\text { Sunflower oil }(0.1 \%) \\
\text { Tween } 80 \text { : Span } 20(0.13 \%)\end{array}$ & $\begin{array}{l}\text { Cymbopogon } \\
\text { citratus } \\
(0.03 \%)\end{array}$ & C & Aspergillus niger & Broccoli & $\begin{array}{l}\text { Ben- } \\
\text { Fadhel et } \\
\text { al. } 2017\end{array}$ \\
\hline Chitosan (16 mg mL-1) & $\begin{array}{l}\text { Origanum vulgare } \\
\left(1.25 \mu \mathrm{gL}^{-1}\right)\end{array}$ & $\mathrm{C}$ & $\begin{array}{l}\text { Rhizopus stolonifer } \\
\text { Aspergillus niger }\end{array}$ & $\begin{array}{l}\text { Cherry } \\
\text { tomato }\end{array}$ & $\begin{array}{l}\text { Barreto et } \\
\text { al. } 2016\end{array}$ \\
\hline
\end{tabular}




\begin{tabular}{|c|c|c|c|c|c|}
\hline Polymeric matrix & EOs & Type & Phytopathogenic fungi & Assay & Reference \\
\hline Chitosan (4 y $\left.8 \mathrm{mg} \mathrm{mL}^{-1}\right)$ & $\begin{array}{l}\text { Mentha piperita L., } \\
\text { Mentha } \times \text { villosa } \\
\text { Huds. } \\
(1.25,2.5,5.0 \mu \mathrm{L} \\
\left.\mathrm{mL}^{-1}\right)\end{array}$ & $\mathrm{C}$ & $\begin{array}{l}\text { Aspergillus niger } \\
\text { Botrytis cinerea } \\
\text { Penicillium expansum } \\
\text { Rhizopus stolonifer }\end{array}$ & Grape & $\begin{array}{l}\text { Guerra et } \\
\text { al. } 2016\end{array}$ \\
\hline Chitosan $\left(4 \mathrm{mg} \mathrm{mL}^{-1}\right)$ & $\begin{array}{l}\text { Mentha piperita, } \\
\text { Mentha } \times \text { villosa } \\
\left(1.25,2.5 \mu \mathrm{L} \mathrm{mL}^{-1}\right)\end{array}$ & $\mathrm{C}$ & $\begin{array}{l}\text { Aspergillus niger } \\
\text { Botrytis cinerea } \\
\text { Penicillium expansum } \\
\text { Rhizopus stolonifer }\end{array}$ & $\begin{array}{l}\text { Cherry } \\
\text { tomato }\end{array}$ & $\begin{array}{l}\text { Guerra et } \\
\text { al. } 2015\end{array}$ \\
\hline $\begin{array}{l}\text { Chitosan }(1.0 \%) \\
\text { Arabic gum }(10 \%) \\
\text { Aloe vera }(2.0 \%)\end{array}$ & $\begin{array}{l}\text { Thymus vulgaris } \\
(1: 1 \text { y } 3: 1)\end{array}$ & C & $\begin{array}{l}\text { Colletotrichum } \\
\text { gloeosporioides }\end{array}$ & Avocado & $\begin{array}{l}\text { Bill et al. } \\
2014\end{array}$ \\
\hline Chitosan (20 mg mL $\left.\mathrm{mL}^{-1}\right)$ & $\begin{array}{l}\text { Origanum vulgare } \\
(1.25,2.5,5.0 \mathrm{~mL} \\
\left.\mathrm{mL}^{-1}\right)\end{array}$ & $\mathrm{C}$ & $\begin{array}{l}\text { Rhizopus stolonifer } \\
\text { Aspergillus niger }\end{array}$ & Grape & $\begin{array}{l}\text { dos Santos } \\
\text { et al. } 2012\end{array}$ \\
\hline $\begin{array}{l}\text { Chitosan }(1.0 \%) \\
\text { Beeswax }(0.1 \%) \text { or oleic } \\
\text { acid }(1.0 \%) \\
\text { Glycerol }(0.3 \%)\end{array}$ & $\begin{array}{l}\text { Lime } \\
\text { Thyme } \\
(0.1 \%)\end{array}$ & $\mathrm{C}$ & Rhizopus stolonifer & Tomato & $\begin{array}{l}\text { Ramos- } \\
\text { García et } \\
\text { al. } 2012\end{array}$ \\
\hline $\begin{array}{l}\text { Modified chitosan }(2.0 \%) \\
\text { Tween } 80(0.4 \%)\end{array}$ & $\begin{array}{l}\text { Oreganum } \\
\text { compactum } \\
\text { Thymus vulgaris } \\
\text { Mentha piperita } \\
\text { Cymbopogon } \\
\text { citratus (DC.) } \\
\text { Stapf. (0.02\%) }\end{array}$ & $\mathrm{C}$ & $\begin{array}{l}\text { Botrytis cinerea } \\
\text { Rhizopus stolonifer }\end{array}$ & Strawberries & $\begin{array}{l}\text { Vu et al. } \\
2011\end{array}$ \\
\hline Chitosan (1.0 g) & $\begin{array}{l}\text { Ocimum basilicum } \\
(0.1,0.3,0.5 \%)\end{array}$ & $\mathrm{F}$ & $\begin{array}{l}\text { Aspergillus niger, A. } \\
\text { flavus } \\
\text { Fusarium sp. } \\
\text { Penicillium sp. }\end{array}$ & In vitro & $\begin{array}{l}\text { Hemalatha } \\
\text { et al. } 2017\end{array}$ \\
\hline $\begin{array}{l}\text { Chitosan }(1 \mathrm{~g}) \\
\text { Tween } 20(0.5 \%)\end{array}$ & $\begin{array}{l}\text { Oregano + Thyme } \\
(1.0 \%)\end{array}$ & $\mathrm{F}$ & Aspergillus niger & In vitro & $\begin{array}{l}\text { Kana and } \\
\text { Meimandi } \\
2017\end{array}$ \\
\hline $\begin{array}{l}\text { Ethylene vinyl alcohol } \\
\text { copolymer (13 g) }\end{array}$ & $\begin{array}{l}\text { Origanum vulgare } \\
\text { Cinnamomum } \\
\text { zeylanicum } \\
(10 \%)\end{array}$ & $\mathrm{F}$ & $\begin{array}{l}\text { Aspergillus flavus, A. } \\
\text { parasiticus }\end{array}$ & In vitro & $\begin{array}{l}\text { Mateo et } \\
\text { al. } 2017\end{array}$ \\
\hline $\begin{array}{l}\text { Chitosan }(0.4 \mathrm{~g}) \\
\text { Carboxymethylcellulose } \\
(0.8 \mathrm{~g}) \\
\text { Tween } 80(0.8 \mathrm{~mL}) \\
\text { Glycerol }(0.2 \mathrm{~mL})\end{array}$ & $\begin{array}{l}\text { Cinnamon } \\
(4.4,8.8,13.2 \%) \\
\text { Ginger } \\
(3.5,7.0,10.6 \%)\end{array}$ & $\mathrm{F}$ & Aspergillus niger & In vitro & $\begin{array}{l}\text { Noshirvani } \\
\text { et al. } 2017\end{array}$ \\
\hline $\begin{array}{l}\text { Cellulose acetate }(8.0 \mathrm{~g}) \\
\text { Acetone }(80 \mathrm{~mL}) \\
\text { Montmorillonite }(0.2 \mathrm{~g})\end{array}$ & $\begin{array}{l}\text { Origanum vulgare } \\
(0,20,40,60 \%)\end{array}$ & $\mathrm{F}$ & $\begin{array}{l}\text { Geotrichum candidum } \\
\text { Rhizopus stolonifer }\end{array}$ & In vitro & $\begin{array}{l}\text { Pola et al. } \\
2016\end{array}$ \\
\hline Poly (lactic acid) (0.5 g) & $\begin{array}{l}\text { Myrtle } \\
\text { Rosemary } \\
\text { Thyme } \\
(0.5,1.5,2.0,5.0 \%)\end{array}$ & $\mathrm{F}$ & Aspergillus niger & In vitro & $\begin{array}{l}\text { Yahyaoui } \\
\text { et al. } 2016\end{array}$ \\
\hline
\end{tabular}




\begin{tabular}{|c|c|c|c|c|c|}
\hline Polymeric matrix & EOs & Type & Phytopathogenic fungi & Assay & Reference \\
\hline $\begin{array}{l}\left.\text { Pullulan (7.5 g } 100 \mathrm{~mL}^{-1}\right) \\
\left.\text { Glycerol (1.5 g } 100 \mathrm{~mL}^{-1}\right)\end{array}$ & $\begin{array}{l}\text { Carum carvi } \\
(0.12,1.25,2.5,5.0 \\
\left.8.0,10 \mathrm{~g} 100 \mathrm{~mL}^{-1}\right)\end{array}$ & $\mathrm{F}$ & $\begin{array}{l}\text { Aspergillus niger } \\
\text { Penicillium expansum }\end{array}$ & Carrot & $\begin{array}{l}\text { Gniewosz } \\
\text { et al. } 2013\end{array}$ \\
\hline $\begin{array}{l}\text { Amaranth flour }(4.0 \%) \\
\text { Chitosan }(1.5 \%) \\
\text { Corn starch }(1.0 \mathrm{~g}) \\
\text { Glycerol }(1.3 \%) \\
\text { Tween } 20(0.5 \%)\end{array}$ & $\begin{array}{l}\text { Lippia berlandieri } \\
\text { Schauer. } \\
\text { Cinnamomum } \\
\text { verum J.Presl. } \\
\text { Cymbopogon } \\
\text { citratus } \\
(0,0.25,0.50,0.75 \text {, } \\
1.0,2.0,4.0 \%)\end{array}$ & $\mathrm{F}$ & $\begin{array}{l}\text { Aspergillus niger } \\
\text { Penicillium digitatum }\end{array}$ & In vitro & $\begin{array}{l}\text { Avila-Sosa } \\
\text { et al. } 2012\end{array}$ \\
\hline $\begin{array}{l}\text { Amaranth flour }(4.0 \%) \\
\text { Chitosan }(1.5 \%) \\
\text { Corn starch }(1.0 \mathrm{~g}) \\
\text { Glycerol }(1.3 \%) \\
\text { Tween } 20(0.5 \%)\end{array}$ & $\begin{array}{l}\text { Lippia berlandieri } \\
(0,0.25,0.50,0.75, \\
1.0,2.0,4.0 \%)\end{array}$ & $\mathrm{F}$ & $\begin{array}{l}\text { Aspergillus niger } \\
\text { Penicillium spp. }\end{array}$ & In vitro & $\begin{array}{l}\text { Avila-Sosa } \\
\text { et al. } 2010\end{array}$ \\
\hline $\begin{array}{l}\text { Chitosan }(0.5 \mathrm{~g}) \\
\text { Caffeic acid }(221 \mathrm{mg})\end{array}$ & $\begin{array}{l}\text { Cuminum cyminum } \\
\text { (100 a } 500 \text { ppm) }\end{array}$ & $\mathrm{N}$ & Aspergillus flavus & In vitro & $\begin{array}{l}\text { Zhaveh et } \\
\text { al. } 2015\end{array}$ \\
\hline
\end{tabular}

$\mathrm{C}=$ coating, $\mathrm{F}=$ film, $\mathrm{N}=$ nanogel.

\section{Conclusions}

EOs have great potential to be used in the control of phytopathogenic fungi. According to the cases reported, it was established that their effect not only occurs in vitro and through its direct application, but also when integrated into coatings and films. This offers a viable alternative for the development of novel technologies, such as the integration of EOs into bioactive packaging (nets, bags, etc.), which would allow their application in different stages of crop development, and perhaps by extending its antifungal effect during the shelf-life of horticultural commodities, the adverse effects of the use of chemical products on consumers and on the environment would be minimized.

\section{Acknowledgment}

The authors would like to thank CONACYT for the financial support provided to carry out this study. 


\section{Literature Cited}

Avila-Sosa R, Hernández-Zamoran E, López-Mendoza I, Palou E, Jiménez M, Nevárez-Moorillón G, LópezMalo A. 2010. Fungal inactivation by Mexican oregano (Lippia berlandieri Schauer) essential oil added to amaranth, chitosan, or starch edible films. Journal of Food Science 75(3): 127-133. https://doi. org/10.1111/j.1750-3841.2010.01524.x

Avila-Sosa R, Palou E, Jiménez MT, Nevárez-Moorillón G, Navarro AM, López-Malo A. 2012. Antifungal activity by vapor contact of essential oils added to amaranth, chitosan, or starch edible films. International Journal of Food Microbiology 153(1-2): 66-72. https://doi.org/10.1016/j.ijfoodmicro.2011.10.017

Badawy MEI, Abdelgaleil SAM. 2014. Composition and antimicrobial activity of essential oils isolated from Egyptian plants against plant pathogenic bacteria and fungi. Industrial Crops and Products 52: 776782. https://doi.org/10.1016/j.indcrop.2013.12.003

Barreto TA, Andrade SCA, Maciel JF, Arcanjo NMO, Madruga MS, Meireles B, Cordeiro AMT, Souza EL, Magnani M. 2016. A chitosan coating containing essential oil from Origanum vulgare L. to control postharvest mold infections and keep the quality of cherry tomato fruit. Frontiers in Microbiology 7: 1724. https://doi.org/10.3389/fmicb.2016.01724

Baser K, Buchbauer G, editors. 2009. Handbook of Essential Oils: Science, Technology, and Applications. CRC Press. Boca Ratón, USA.

Ben-Fadhel Y, Saltaji S, Khlifi M, Salmieri S, Dang VK, Lacroix M. 2017. Active edible coating and $\gamma$-irradiation as cold combined treatments to assure the safety of broccoli florets (Brassica oleracea L.). International Journal of Food Microbiology 241: 3038. https://doi.org/10.1016/j.ijfoodmicro.2016.10.010

Bill M, Sivakumar D, Korsten L, Thompson AK. 2014. The efficacy of combined application of edible coatings and thyme oil in inducing resistance components in avocado (Persea americana Mill.) against anthracnose during postharvest storage. Crop Protection 64: 159-167. https://doi.org/10.1016/j. cropro.2014.06.015

Black-Solis J, Ventura-Aguilar RI, Barrera-Necha LL, Bautista-Baños S. 2017. Caracterización química, variabilidad composicional y modelamiento matemático del efecto de aceites esen- ciales en Alternaria alternata. Revista Mexicana de Fitopatología 35(2): 204-226. https://doi. org/10.18781/R.MEX.FIT.1612-5

Bosquez-Molina E, Ronquillo-de Jesús E, BautistaBaños S, Verde-Calvo JR, Morales-López J. 2010. Inhibitory effect of essential oils against Colletotrichum gloeosporioides and Rhizopus stolonifer in stored papaya fruit and their possible application in coatings. Postharvest Biology and Technology 57: 132-137. https://doi.org/10.1016/j. postharvbio.2010.03.008

Camele I, De Feo V, Altieri L, Mancini E, De Martino L, Luigi G. 2010. An attempt of postharvest orange fruit rot control using essential oils from Mediterranean plants. Journal of Medicinal Food 13(6): 1515-1523. https://doi.org/10.1089/jmf.2009.0285

Castro JC, Endo EH, de Souza MR, Zanqueta EB, Polonio JC, Pamphile JA, Ueda-Nakamura T, Nakamura CV, Dias BP, de Abreu Filho BA. 2017. Bioactivity of essential oils in the control of Alternaria alternata in dragon fruit (Hylocereus undatus Haw.). Industrial Crops and Products 97: 101-109. https:// doi.org/10.1016/j.indcrop.2016.12.007

Chen Q, Xu S, Wu T, Guo J, Sha S, Zheng X, Yu T. 2014. Effect of citronella essential oil on the inhibition of postharvest Alternaria alternata in cherry tomato. Journal of the Science of Food and Agriculture 94(12): 2441-2447. https://doi.org/10.1002/jsfa.6576

Costa L, Pinto J, Bertolucci S, Costa J, Alves P, Niculau E. 2015. In vitro antifungal activity of Ocimum selloi essential oil and methylchavicol against phytopathogenic fungi. Revista Ciência Agronômica 46(2): 428435. https://doi.org/10.5935/1806-6690.20150023

de Sousa LL, de Andrade SC, Athayde AJ, de Oliveira CE, de Sales CV, Madruga MS, de Souza EL. 2013. Efficacy of Origanum vulgare L. and Rosmarinus officinalis L. essential oils in combination to control postharvest pathogenic aspergilli and autochthonous mycoflora in Vitis labrusca L. (table grapes). International Journal of Food Microbiology 165(3): 312-318. https://doi. org/10.1016/j.ijfoodmicro.2013.06.001

Dima C, Dima S. 2015. Essential oils in foods: Extraction, stabilization, and toxicity. Current Opinion in Food Science 5: 29-35. https://doi. org/10.1016/j.cofs.2015.07.003

Dimić G, Kocić-Tanackov S, Mojović L, Pejin J. 2014. Antifungal activity of lemon essential oil, corian- 
der and cinnamon extracts on foodborne molds in direct contact and the vapor phase. Journal of Food Processing and Preservation 39(6): 1778-1787. https://doi.org/10.1111/jfpp.12410

Djihane B, Wafa N, Elkhamssa S, Pedro HJ, Maria AE, M Z. 2017. Chemical constituents of Helichrysum italicum (Roth) G. Don essential oil and their antimicrobial activity against Gram-positive and Gramnegative bacteria, filamentous fungi and Candida albicans. Saudi Pharmaceutical Journal 25(5): 780787. https://doi.org/10.1016/j.jsps.2016.11.001

dos Santos NS, Athayde AJ, de Oliveira CE, Veríssimo C, de Melo S, Sousa R, Stamford TC, de Souza EL. 2012. Efficacy of the application of a coating composed of chitosan and Origanum vulgare L. essential oil to control Rhizopus stolonifer and Aspergillus niger in grapes (Vitis labrusca L.). Food Microbiology 32(2): 345-353. https://doi. org/10.1016/j.fm.2012.07.014

Elshafie HS, Aliberti L, Amato M, De Feo V, Camele I. 2018. Chemicalcompositionand antimicrobialactivity of chia (Salvia hispanica L.) essential oil. European Food Research and Technology 244(9): 16751682. https://doi.org/10.1007/s00217-018-3080-x Elshafie HS, Grul'ová D, Baranová B, Caputo L, De Martino L, Sedlák V, Camele I, De Feo V. 2019. Antimicrobial activity and chemical composition of essential oil extracted from Solidago canadensis L. growing wild in Slovakia. Molecules 24(7): E1206. https://doi.org/10.3390/molecules24071206

Franz C, Novak J. 2009. Sources of essential oils. In: Baser K, Buchbauer G, editors. Handbook of Essential Oils: Science, Technology, and Applications. Boca Ratón, CRC Press. P. 39-81.

Gemeda N, Woldeamanuel Y, Asrat D, Debella A, Belete Y. 2015. Assessment of Lippia adoensis Hochst. var. koseret, Rosmarinus officinalis L. and Ruta chalepensis L. essential oils as a potential source of fungitoxic and mycosporicidal activity against toxigenic Aspergillus species. PharmacologyOnlLine Archives 2: 85-94.

Gniewosz M, Kraśniewska K, Woreta M, Kosakowska O. 2013. Antimicrobial activity of a pullulan-caraway essential oil coating on reduction of food microorganisms and quality in fresh baby carrot. Journal of Food Science 78(8): M1242-M1248. https://doi.org/10.1111/1750-3841.12217
Guerra IC, de Oliveira PD, Pontes AL, Lúcio AS, Tavares JF, Barbosa-Filho JM, Madruga M, de Souza E. 2015. Coatings comprising chitosan and Mentha piperita L. or Mentha× villosa Huds essential oils to prevent common postharvest mold infections and maintain the quality of cherry tomato fruit. International Journal of Food Microbiology 214: 168-178. https:// doi.org/10.1016/j.ijfoodmicro.2015.08.009

Guerra IC, de Oliveira PD, Santos MM, Lúcio SS, Tavares J, Barbosa-Filho J, Madruga M, de Souza E. 2016. The effects of composite coatings containing chitosan and Mentha (piperita L. or x villosa Huds) essential oil on postharvest mold occurrence and quality of table grape cv. Isabella. Innovative Food Science \& Emerging Technologies 34: 112-121. https://doi.org/10.1016/j.ifset.2016.01.008

Guleria S, Tiku AK, Gupta S, Gurjinder S, Koul A, Razdan VK. 2012. Chemical composition, antioxidant activity and inhibitory effects of essential oil of Eucalyptus teretecornis grown in north-western Himalaya against Alternaria alternata. Journal of Plant Biochemistry and Biotechnology 21(1): 4450. https://doi.org/10.1007/s13562-011-0073-2

Haddouchi F, Chaouche TM, Zaouali Y, Ksouri R, Attou A, Benmansour A. 2013. Chemical composition and antimicrobial activity of the essential oils from four Ruta species growing in Algeria. Food Chemistry 141(1): 253-258. https://doi. org/10.1016/j.foodchem.2013.03.007

Hamdani F, Allem R. 2015. Propriétés antifongiques des huiles essentielles des feuilles de Citrus vis-àvis d'Alternaria alternata et Penicillium sp in vitro. Phytothérapie 15: 263-266. https://doi.org/10.1007/ s10298-015-0978-3

Hemalatha T, UmaMaheswari T, Senthil R, Krithiga G, Anbukkarasi K. 2017. Efficacy of chitosan films with basil essential oil: Perspectives in food packaging. Journal of Food Measurement and Characterization 11(4): 2160-2170. https:/doi. org/10.1007/s11694-017-9601-7

Isman MB. 2000. Plant essential oils for pest and disease management. Crop Protection 19(8-10): 603608. https://doi.org/10.1016/s0261-2194(00)00079-x

Juliano C, Marchetti M, Campagna P, Usai M. 2019. Antimicrobial activity and chemical composition of essential oil from Helichrysum microphyllum 
Cambess. subsp. tyrrhenicum Bacch., Brullo \& Giusso collected in South-West Sardinia. Saudi Journal of Biological Sciences 26(5): 897-905. https://doi.org/10.1016/j.sjbs.2018.04.009

Kedia A, Prakash B, Mishra PK, Chanotiya CS, Dubey NK. 2014a. Antifungal, antiaflatoxigenic, and insecticidal efficacy of spearmint (Mentha spicata L.) essential oil. International Biodeterioration \& Biodegradation 89: 29-36. https://doi.org/10.1016/j. ibiod.2013.10.027

Kedia A, Prakash B, Mishra PK, Dubey NK. 2014 b. Antifungal and antiaflatoxigenic properties of Cuminum cyminum (L.) seed essential oil and its efficacy as a preservative in stored commodities. International Journal of Food Microbiology 168-169: $\quad$ 1-7. $\quad$ https://doi.org/10.1016/j. ijfoodmicro.2013.10.008

Kedia A, Dwivedy AK, Jha DK, Dubey NK. 2015. Efficacy of Mentha spicata essential oil in suppression of Aspergillus flavus and aflatoxin contamination in chickpea with particular emphasis to mode of antifungal action. Protoplasma 253(3): 647-653. https://doi.org/10.1007/s00709-015-0871-9

Khosravi AR, Mohammad R, Yahyaraeyat R, Mokhtari AR, Panahi P. 2015. Chemical composition and antifungal activity of Trachyspermum copticum essential oil against Alternaria alternata (In-vitro study). Journal of Medicinal Plants 1(53): 82-88.

Kloucek P, Smid J, Frankova A, Kokoska L, Valterova I, Pavela R. 2012. Fast screening method for assessment of antimicrobial activity of essential oils in vapor phase. Food Research International 47(2): 161165. https://doi.org/10.1016/j.foodres.2011.04.044

Kocić-Tanackov S, Dimić G. 2013. Antifungal activity of essential oils in the control of food-borne fungi growth and mycotoxin biosynthesis in food. In: Méndez-Vilas A, editor. Microbial Pathogens and Strategies for Combating them: Science, Technology and Education. Badajoz. Formatex Research Center. P. 838-849.

Krisch J, Rentsenkhand T, Vágvölgyi C. 2011. Essential oils against yeasts and moulds causing food spoilage. In: Méndez-Vilas A, editor. Science Against Microbial Pathogens: Communicating Current Research and Technological Advances. Badajoz. Formatex Research Center. P. 1135-1142.
Kubeczka K. 2009. History and sources of essential oil research. In: Baser K, Buchbauer G, editors. Handbook of Essential Oils: Science, Technology, and Applications. Boca Ratón, CRC Press. P. 3-38.

Lu M, Han Z, Xu Y, Yao L. 2013. Effects of essential oils from Chinese indigenous aromatic plants on mycelial growth and morphogenesis of three phytopathogens. Flavour and Fragrance Journal 28(2): 84-92. https://doi.org/10.1002/ffj.3132

Ma B, Ban X, Huang B, He J, Tian J, Zeng H, Chen Y, Wang Y. 2015a. Interference and mechanism of dill seed essential oil and contribution of carvone and limonene in preventing Sclerotinia rot of rapeseed. PloS ONE 10(7): e0131733. https://doi.org/10.1371/ journal.pone.0131733

Ma Q, Fan X-D, Liu X-C, Qiu T-Q, Jiang J-G. 2015b. Ultrasound-enhanced subcritical water extraction of essential oils from Kaempferia galangal L. and their comparative antioxidant activities. Separation and Purification Technology 150: 73-79. https://doi. org/10.1016/j.seppur.2015.06.013

Mahmoudi E, Ahmadi A, Naderi D. 2012. Effect of Zataria multiflora essential oil on Alternaria alternata in vitro and in an assay on tomato fruits. Journal of Plant Diseases and Protection 119(2): 53-58. https:// doi.org/10.1007/bf03356420

Mamgain A, Roychowdhury R, Tah J. 2013. Alternaria pathogenicity and its strategic controls. Research Journal of Biology 1: 1-9.

Mandal S, Mandal M. 2015. Coriander (Coriandrum sativum L.) essential oil: Chemistry and biological activity. Asian Pacific Journal of Tropical Biomedicine 5(6): 421-428. https://doi.org/10.1016/j. apjtb.2015.04.001

Manganyi MC, Regnier T, Olivier EI. 2015. Antimicrobial activities of selected essential oils against Fusarium oxysporum isolates and their biofilms. South African Journal of Botany 99: 115-121. https://doi.org/10.1016/j.sajb.2015.03.192

Mansoreh S, Ghasemi A, AdibNejad M. 2015. Chemical composition and yield of essential oils from bakhtiari savory (Satureja bachtiarica Bunge.) under different extraction methods. Industrial Crops and Products 76: 809-816. https://doi.org/10.1016/j. indcrop.2015.07.068

Martins C, Natal-da-Luz T, Sousa JP, Gonçalves MJ, Salgueiro L, Canhoto C. 2013. Effects of essential oils 
from Eucalyptus globulus leaves on soil organisms involved in leaf degradation. PloS ONE 8(4): e61233. https://doi.org/10.1371/journal.pone.0061233

Mashigo M, Combrinck S, Regnier T, Du Plooy W, Augustyn W, Mokgalaka N. 2015. Chemical variations, trichome structure and antifungal activities of essential oils of Helichrysum splendidum from South Africa. South African Journal of Botany 96: 78-84. https://doi.org/10.1016/j.sajb.2014.10.006

Mateo EM, Gómez JV, Domínguez I, GimenoAdelantado JV, Mateo-Castro R, Gavara R, Jiménez M. 2017. Impact of bioactive packaging systems based on EVOH films and essential oils in the control of aflatoxigenic fungi and aflatoxin production in maize. International Journal of Food Microbiology 254: 36-46. https://doi.org/10.1016/j. ijfoodmicro.2017.05.007

Matusinsky P, Zouhar M, Pavela R, Novy P. 2015. Antifungal effect of five essential oils against important pathogenic fungi of cereals. Industrial Crops and Products 67: 208-215. https://doi.org/10.1016/j. indcrop.2015.01.022

McCarroll N, Protzel A, Ioannou Y, Frank HF, Jackson MA, Waters MD, Dearfield KL. 2002. A survey of EPA/OPP and open literatura on selected pesticide chemicals III. Mutagenicity and carcinogenicity of benomyl and carbendazim. Review. Mutation Research/Reviews in Mutation Research 512: 1-35. https://doi.org/10.1016/S1383-5742(02)00026-1

Mehra LK, MacLean DD, Shewfelt RL, Smith KC, Scherm H. 2013. Effect of postharvest biofumigation on fungal decay, sensory quality, and antioxidant levels of blueberry fruit. Postharvest Biology and Technology 85: 109-115. https://doi.org/10.1016/j. postharvbio.2013.05.007

Mohammadi A, Nazari H, Imani S, Amrollahi H. 2014. Antifungal activities and chemical composition of some medicinal plants. Journal de Mycologie Médicale 24(2): e1-e8. https://doi.org/10.1016/j. mycmed.2014.02.006

Noshirvani N, Ghanbarzadeh B, Gardrat C, Rezaei MR, Hashemi M, Le Coz C, Coma V. 2017. Cinnamon and ginger essential oils to improve antifungal, physical and mechanical properties of chitosan-carboxymethyl cellulose films. Food Hydrocolloids 70: 36-45. https://doi.org/10.1016/j. foodhyd.2017.03.015
Ouattara B, Simard R, Piette G, Bégin A, Holley RA. 2000. Inhibition of surface spoilage bacteria in processed meats by application of antimicrobial films prepared with chitosan. International Journal of Food Microbiology 62(1-2): 139-148. https://doi. org/10.1016/s0168-1605(00)00407-4

PavlićB, VidovićS, VladićJ, Radosavljević R, ZekovićZ . 2015. Isolation of coriander (Coriandrum sativum L.) essential oil by green extractions versus traditional techniques. The Journal of Supercritical Fluids 99: 23-28. https://doi.org/10.1016/j.supflu.2015.01.029

Pekmezovic M, Rajkovic K, Barac A, Senerović L, Arsic V. 2015. Development of kinetic model for testing antifungal effect of Thymus vulgaris L. and Cinnamomum cassia L. essential oils on Aspergillus flavus spores and application for optimization of synergistic effect. Biochemical Engineering Journal 99: 131-137. https://doi.org/10.1016/j.bej.2015.03.024

Perina F, Amaral D, Fernandes R, Labory C, Teixeira $\mathrm{G}$, Alves E. 2014. Thymus vulgaris essential oil and thymol against Alternaria alternata (Fr.) Keissler: Effects on growth, viability, early infection and cellular mode of action. Pest Management Science 71(10): 1371-1378. https://doi.org/10.1002/ps.3933

Phillips CA, Laird K, Allen SC. 2012. The use of Citri-V $\mathrm{V}^{\mathrm{TM}}-\mathrm{An}$ antimicrobial citrus essential oil vapour for the control of Penicillium chrysogenum, Aspergillus niger and Alternaria alternata in vitro and on food. Food Research International 47(2): 310314. https://doi.org/10.1016/j.foodres.2011.07.035

Pola CC, Medeiros EAA, Pereira OL, Souza VGL, Otoni CG, Camilloto GP, Soares NFF. 2016. Cellulose acetate active films incorporated with oregano (Origanum vulgare) essential oil and organophilic montmorillonite clay control the growth of phytopathogenic fungi. Food Packaging and Shelf life 9: 69-78. https://doi.org/10.1016/j.fpsl.2016.07.001

Ramos-García M, Bosquez-Molina E, HernándezRomano J, Zavala-Padilla G, Terrés-Rojas E, AliaTejacal I, Barrera-Necha L, Hernández-López M, Bautista-Baños S. 2012. Use of chitosan-based edible coatings in combination with other natural compounds, to control Rhizopus stolonifer and Escherichia coli DH5 $\alpha$ in fresh tomatoes. Crop Protection 38: 1-6. https://doi.org/10.1016/j.cropro.2012.02.016

Raphaël KJ, Meimandipour A. 2017. Antimicrobial activity of chitosan film forming solution enriched with 
essential oils; an in vitro assay. Iranian Journal of Biotechnology 15(2): 111-119. https://doi.org/10.15171/ ijb.1360

Raut J, Karuppayil S. 2014. A status review on the medicinal properties of essential oils. Industrial Crops and Products 62: 250-264. https://doi.org/10.1016/j. indcrop.2014.05.055

Ray A, Jena S, Dash B, Kar B, Halder T, Chatterjee T, Chatterjee T, Ghosh B, Chandra P, Nayak S, Mahapatra N. 2018. Chemical diversity, antioxidant and antimicrobial activities of the essential oils from Indian populations of Hedychium coronarium Koen. Industrial Crops and Products 112: 353-362. https:// doi.org/10.1016/j.indcrop.2017.12.033

Rguez S, Msaada K, Daami-Remadi M, Chayeb I, Rebey I, Hammami M, Laarif A, Hamrouni-Sellami I. 2019. Chemical composition and biological activities of essential oils of Salvia officinalis aerial parts as affected by diurnal variations. Plant Biosystems - An International Journal Dealing with all Aspects of Plant Biology 153(2): 264-272. https://doi.org/10.1080/11263504.2018 .1473305

Riaz M, Rasool N, Bukhari I, Shahid M, Zubair M, Rizwan K, Rashid U. 2012. In vitro antimicrobial, antioxidant, cytotoxicity and GC-MS analysis of Mazus goodenifolius. Molecules 17(12): 14275-14287. https:// doi.org/10.3390/molecules171214275

Rivera J, Crandall P, O'Bryan CA, RickeSC. 2015. Essential oils as antimicrobials in food systems-a review. Food Control 54: 111-119. https://doi.org/10.1016/j. foodcont.2014.12.040

Ruiz J, Vicente AA, Montañéz JC, Rodríguez R, Aguilar CN. 2012. Un tesoro perecedero en México: el tomate, tecnologías para prolongar su vida de anaquel. Investigación y Ciencia: de la Universidad Autónoma de Aguascalientes 54: 57-63.

Salah-Fatnassi KBH, Hassayoun F, Cheraif I, Khan S, Jannet HB, Hammami M, Aouni M, HarzallahSkhiri F. 2017. Chemical composition, antibacterial and antifungal activities of flowerhead and root essential oils of Santolina chamaecyparissus L., growing wild in Tunisia. Saudi Journal of Biological Sciences 24(4): 875-882. https://doi.org/10.1016/j. sjbs.2016.03.005

Sánchez-González L, Vargas M, González-Martínez C, Chiralt A, Cháfer M. 2011. Use of essential oils in bioactive edible coatings: a review.
Food Engineering Reviews 3(1): 1-16. https://doi. org/10.1007/s12393-010-9031-3

Šarac Z, Matejić JS, Stojanović-Radić ZZ, Veselinović JB, Džamić AM, Bojović S, Marin PD. 2014. Biological activity of Pinus nigra terpenes-evaluation of FtsZ inhibition by selected compounds as contribution to their antimicrobial activity. Computers in Biology and Medicine 54: 72-78. https://doi.org/10.1016/j. compbiomed.2014.08.022

Saroj A, Pragadheesh V, Yadav A, Singh S, Samad A, Negi A, Chanotiya C. 2015. Anti-phytopathogenic activity of Syzygium cumini essential oil, hydrocarbon fractions and its novel constituents. Industrial Crops and Products 74: 327-335. https://doi.org/10.1016/j. indcrop.2015.04.065

Schmidt E. 2009. Production of essential oils. In: Baser K, Buchbauer G, editors. Handbook of Essential Oils: Science, Technology, and Applications. Boca Ratón, CRC Press. P. 83-119.

Sell C. 2009. Chemistry of essential oils. In: Baser K, Buchbauer G, editors. Handbook of Essential Oils: Science, Technology, and Applications. Boca Ratón, CRC Press. P. 121-150.

Shao X, Cheng S, Wang H, Yu D, Mungai C. 2013. The possible mechanism of antifungal action of tea tree oil on Botrytis cinerea. Journal of Applied Microbiology 114(6): 1642-1649. https://doi.org/10.1111/jam.12193

Singh P, Shukla R, Prakash B, Kumar A, Singh S, Mishra P, Dubey N. 2010. Chemical profile, antifungal, antiaflatoxigenic and antioxidant activity of Citrus maxima Burm. and Citrus sinensis (L.) Osbeck essential oils and their cyclic monoterpene, DL-limonene. Food and Chemical Toxicology 48(6): 1734-1740. https://doi.org/10.1016/j.fct.2010.04.001 Singh P, Kumar R, Prakash O, Pant AK, Kumar M, Isidorov V, Szczepaniak L. 2019. Chemical composition, anti-inflammatory, analgesic, antipyretic, myorelaxant, antibacterial and antifungal activity of Rabdosia rugosus Wall. (Syn. Plectranthus rugosus Wall.). Journal of Medicinal Herbs and Ethnomedicine 5: 8-15. https://doi.org/10.25081/ jmhe.2019.v5.3831

Stević T, Berić T, Šavikin K, Soković M, Gođevac D, Dimkić I, Stanković S. 2014. Antifungal activity of selected essential oils against fungi isolated from medicinal plant. Industrial Crops and Products 55: 116122. https://doi.org/10.1016/j.indcrop.2014.02.011 
Tian J, Ban X, Zeng H, He J, Huang B, Wang Y. 2011a. Chemical composition and antifungal activity of essential oil from Cicuta virosa L. var. latisecta Celak. InternationalJournalofFoodMicrobiology145(2-3):464470. https://doi.org/10.1016/j.ijfoodmicro.2011.01.023

Tian J, Ban X, Zeng H, Huang B, He J, Wang Y. 2011b. In vitro and in vivo activity of essential oil from dill (Anethum graveolens L.) against fungal spoilage of cherry tomatoes. Food Control 22(12): 1992-1999. https:// doi.org/10.1016/j.foodcont.2011.05.018

Torrenegra ME, Granados C, Osorio MR, León G. 2015. Comparación de la Hidro-destilación asistida por radiación de microondas (MWHD) con Hidrodestilación convencional (HD) en la extracción de aceite esencial de Minthostachys mollis. Información Tecnológica 26(1): 117-122. https://doi.org/10.4067/ s0718-07642015000100013

Van de Vel E, Sampers I, Raes K. 2019. A review on influencing factors on the minimum inhibitory concentration of essential oils. Critical Reviews in Food Science and Nutrition 59(3): 357-378. http://doi.org/10.1080/104 08398.2017.1371112

Vu KD, Hollingsworth RG, Leroux E, Salmieri S, Lacroix M. 2011. Development of edible bioactive coating based on modified chitosan for increasing the shelf life of strawberries. Food Research International 44(1): 198203. https://doi.org/10.1016/j.foodres.2010.10.037

Wink M. 2010. Function and biotechnology of plant secondary metabolites. Annual Plant Reviews, Volumen 39. Wiley-Blackwell. West Sussex, UK.

Xu S, Yan F, Ni Z, Chen Q, Zhang H, Zheng X. 2014. In vitro and in vivo control of Alternaria alternata in cherry tomato by essential oil from Laurus nobilis of Chinese origin. Journal of the Science of Food and Agriculture 94(7): 1403-1408. https://doi.org/10.1002/jsfa.6428

Yahyaoui M, Gordobil O, Herrera R, Abderrabba M, Labidi J. 2016. Development of novel antimicrobial films based on poly (lactic acid) and essential oils. Reactive and Functional Polymers 109: 1-8. https://doi. org/10.1016/j.reactfunctpolym.2016.09.001

Zabka M, Pavela R, Prokinova E. 2014. Antifungal activity and chemical composition of twenty essential oils against significant indoor and outdoor toxigenic and aeroallergenic fungi. Chemosphere 112: 443-448. https://doi.org/10.1016/j.chemosphere.2014.05.014
Zebarjad Z, Farjam M. 2015. Evaluation of antimicrobial activity of essential oils from different parts of Anthemis odontostephana Boiss. var. odontostephana. International Journal of Pharmacognosy and Phytochemical Research 7(3): 579-584.

Zhang X, Guo Y, Guo L, Jiang H, Ji Q. 2018. In vitro evaluation of antioxidant and antimicrobial activities of Melaleuca alternifolia essential oil. BioMed Research International 2018: Article ID 2396109. https://doi. org/10.1155/2018/2396109

Zhaveh S, Mohsenifar A, Beiki M, Khalili S, Abdollahi A, Rahmani-Cherati T, Tabatabaei M. 2015. Encapsulation of Cuminum cyminum essential oils in chitosan-caffeic acid nanogel with enhanced antimicrobial activity against Aspergillus flavus. Industrial Crops and Products 69: 251-256. https:// doi.org/10.1016/j.indcrop.2015.02.028

Znini M, Cristofari G, Majidi L, Paolini J, Desjobert J, Costa J. 2013. Essential oil composition and antifungal activity of Pulicaria mauritanica Coss., against postharvest phytopathogenic fungi in apples. LWTFood Science and Technology 54(2): 564-569. https:// doi.org/10.1016/j.lwt.2013.05.030 